\title{
CERCETĂRI ARHEOLOGICE PREVENTIVE ÎN ZONA BALOTEŞTI (JUD. ILFOV)
}

Ovidiu Tentea, Sorin Cleşiu, Mihai Florea, Corina Borş, Alexandru Rạ̧iu

\section{PREVENTIVE ARCHAEOLOGICAL RESEARCHES IN BALOTEŞTI AREA (ILFOV COUNTY)}

A series of preliminary evidences concerning the archaeological sites along the banks of the Cociovaliște valley were indicated in the 80 s and ' 90 s throughout a series of field-walkings in the area. Yet, during the last decade, the residential development in the areas north to Bucharest impacted such vestiges, only in few cases being possible to undertake a preventive research prior to the construction works. This study provides an insight upon a preliminary analysis of landscape archaeology in the Baloteşti area, as well as presents the results of the archaeological excavations conducted on a plot of land, situated on the right bank of the Cociovalişte valley. Significantly damaged by subsequent agricultural works and other human activities, the archaeological contexts investigated in here provided a rather large quantity of fragmentary pottery, dated to the $2^{\text {nd }}-1^{\text {st }} \mathrm{c}$. AD, certain vessels having analogies on other Late Latène sites from the south-eastern part of nowadays Romania.

Keywords: preventive archaeology, landscape archaeology, Late Latène pottery, amphorae.

Cuvinte cheic: arheologie preventivă, arheologie a peisajului, ceramică Latène târziu, amfore.

\section{Considerații generale}

Studiul de fặă prezintă rezultatele cercetărilor arheologice preventive efectuate în toamna anului 2008 - de către un colectiv de arheologi din cadrul Muzeului Naţional de Istorie a României' în zona de mijloc a văii Cociovaliştei, în aria de nord a judeţului Ilfov. Într-o primă etapă, obiectivele acestor cercetări l-au constituit, pe de o parte, identificarea şi documentarea vestigiilor arheologice existente pe terenul localizat în str. Florilor, tarlaua 103, parcela A381/31-36, sat Baloteşti (fost sat Preoţeşti), comuna Baloteşti, judeţul Ilfov, proprictate S.C. Flower City S.R.L. (planşa 1), iar, pe de altă parte, evaluarea preliminară a potenţialului arheologic al zonelor imediat învecinate cu acestea (planşa 3). Pornind de la datele specifice conţinute în documentaţii de urbanism (PUG Baloteşti), ce preluau

\footnotetext{
'Evaluarea și cercetarea arheologican au fost realizate de un colectiv formal din: Paul Damian - responsabil, Ovidiu Tentea. Corina Borş. Sorin Cleşiu, Milhai Florea. Cătălin Lazãr, Alexandru Raţiu: pentru rezultatele preliminare ale acestor cercetări arheologice vezi Damian et alii 2009, 258-259.
}

informaţii anterioare referitoare la existenţa unor vestigii arheologic semnalate în literatura de specialitate şi Lista Monumentelor Istorice din județul Ilfov (2004), existau o serie de indicii relativ concludente care au determinat realizarea unei evaluări teoretice şi de teren, unnată de o cercetare arheologică preventivă, menite să identifice, să delimiteze şi să studieze potenţialul arheologic din perimetrul dat, toate acestea constituind etape obligatorii - potrivit legislaţiei relevante aplicabile- pentru obţinerea avizelor necesare în vederea eliberării autorizaţiei de construire pentru edificarea unui proiect rezidenţial.

Astfel, cu prilejul evaluării de teren (efectuată în prima jumătate a lunii octombrie 2008), întreaga suprafaţă a lotului în discuţie (3 ha) a fost investigată preliminar prin efectuarea unor secţiuni de sondaj, realizate cu ajutorul unui utilaj mecanic şi sub supraveghere arheologică în vederea stabilirii existenţei unor vestigii arheologice şi delimitării zonei cu potenţial arheologic cert. La finalul acestor prime lucrări arheologice de specialitate a fost 
redactat un raport de evaluare, fiind delimitată o suprafaţă de 0,75 ha unde s-au observat urme de interventii antropice de interes istoricoarheologic (planşa 6). Studiul de evaluare a potenţialului arheologic în cuprinsul perimetrului proprietăţii S.C. Flower City S.R.L. a confirmat existenta unor urme de locuire databile în perioada Latène, iar analiza preliminară a materialului ceramic recoltat $\mathbf{a}$ indicat o încadrare cronologică în secolele II-I a. Chr.

În atare condiţii, într-o a doua etapă, cercetarea arheologică preventivă a urmărit să determine, pe cât este posibil, natura şi distribuţia bunurilor de patrimoniu arheologic (imobile şi mobile) din zona direct afectată de viitoarele lucrări de construire, respectiv — pornind de la conceptul de "salvgardare prin inregistrare" investigarea propriu-zisă a acestora prin cfectuarca de cercetări arheologice, înregistrarea şi analiza post-săpătură a descoperirilor, care să permită parcurgerea procedurii de descărcare de sarcină arheologică pentru terenul proprietate a beneficiarului, pe care unna să fie construit un ansamblu rezidenţial.

\section{Cadrul fizico-geografic}

Terenul pe care au fost efectuate, în toamna anului 2008 , cercetările arheologice preventive se află situat pe malul drept al văii Cociovaliştei, curs de apă care a suferit importante modificări şi amenajări antropice în cursul ultimului secol. Din mărturiile unor localnici, pe terenul unde s-a desfăşurat cercetarea de fał̧ă a existat în a doua jumătate a secolului trecut o livadă expcrimentală a unei staţiuni de cercetare în domeniul zootehniei, care a fost dezafectată în cursul ultimului

\footnotetext{
2 Termenul ca atare nu este unul uzual în teoria și practica arheologicã actualā din România. cu atât mai puḷin în legislaţia aplicabilă arheologiei/protejării patrimoniului arheologic. atunci când este vorba de cercetãri arheologice preventive/de salvare. dar el este uzitat în domeniile respective din alte jări precum Marea Britanie sau SUA, iar mai recent Franta. Pentru înţelesul general al termenului şi utilizarea sa vezi Roskams 2001, 35-36: Grant et alii 2005, 27-28. 128-129: PPG16. sec(iunea 25 (actualizată în 2010 prin PP'S5, 11): Neumann, Sanford 2001, 201-242: Green 2002. 104-105: Grant el alii 2005. 129. respectiv sensul acestuia potrivit legislaţiei lranceze aplicabile arheologici preventive, respectiv Legea nr. 2001-44/200! (cu completările ulterioare).
}

deceniư ${ }^{3}$. Această informaţie a fost confirmată atât printr-o adeverinţă emisă de Primăria Baloteşti, cât şi de observaţiile directe efectuate pe o serie de imagini aeriene verticale.

Din punct de vedere geomorfologic, zona în care se află amplasat situl se încadrează în grupa regiunilor loessoide a Câmpiei Române, subunitatea Câmpia Vlăsiei, numită şi Câmpia tabulară a Vlăsiei ${ }^{4}$. Caracterul divergent al teraselor, mulţimea crovurilor, existenţa unui mic sector de dune, degradarea incipientă a reţelelor hidrografice, mulţimea limanelor fluviatile sunt caracteristicile ce individualizează Câmpia Vlăsiei $i^{5}$. Din Câmpia Vlăsiei face parte şi subunitatea Câmpia Snagovului cu altitudini cuprinse între 80-130 $\mathrm{m}$, dominată de lacuri de tip liman-fluviatil (Bălteni, Snagov, Căldăruşani) ${ }^{6}$, astăzi acestea fiind alimentate şi cu apele lalomiţei prin sistemul Bilciureşti şi prin văile de tip „mostişte" care se varsă în $\mathrm{ele}^{7}$. În această câmpie au avut loc importante schimbări în textura hidrografică (inclusiv de-a lungul fostului pârâu Cociovaliște sau Pociovalişte), astfel că necesitatea de utilizare a apei pentru agricultură a fost asigurată prin sistemele de irigaţii şi lucrări de amenajare a unor lacuri artificiale (iazuri, eleşteie) în acest areal ${ }^{8}$. Practic această câmpie se individualizează în cadrul Câmpiei Române de vest, prin aşa numita „câmpie tabulară” (cu terase) care se află situată în sudul zonei de subzistenţă, unde, aşa cum am arătat, se întind câmpuri netede, largi, acoperite de depozite loessoide, loess şi, local, dune de nisip. Câmpurile se termină prin terase către văile principale ce le despart (Dunărea în primul rând, apoi Dâmbovita, cel puţin de la Bucureşti în jos, Mostiştea, Ialomiţa). $\mathrm{Cu}$ excepţia Vlăsiei, care este

\footnotetext{
${ }^{3}$ Informalie furnizată de către dl. Tiberiu Nicolescu, fost angajat al acestei stạ̧iuni de cercetare. Dupá cooperativizarítoată peninsula unde este situat terenul în discuḷic a tus ulilizatã pentru culturi furajere, jar din anii 60 a lost ammenajată ca livadă.

${ }^{4}$ Roşu 1980. 441.

${ }^{5}$ Colef 1973, 374.

${ }^{6}$ Ujvári 1972, 467; Cotel 1976, 188.

${ }^{7}$ Ujvári 1972, 468.

8 Cotef 1976. 133.

9 Mihăilescu 1969. 140-142.
} 
fragmentată şi destul de împădurită spre nord (mai ales în Câmpia Snagovului), întreaga câmpie estică tabulară este o regiune de silvostepă. acum cu prea puţine păduri, şi de stepă cu graminee, intens cultivată în ultimele decenii, iar mai recent transformată treptat în zonă rezidenţială. Această câmpie a fost din vremurile preistorice până astăzi relativ populată şi a servit drept punte de legătură între zona colinară şi valea Dunăriií ${ }^{10}$.

Din punct de vedere administrativ situl se aflà în localitatea Baloteşti, comuna Baloteşti, judef̧ul Ilfov, la aproximativ 1,6 km est de DN I Bucureşti - Ploiești şi la aproximativ $282 \mathrm{~m}$ nord de DJ 101, pe un promontoriu înconjurat din trei părţi de un meandru larg al pârâului Cociovaliştea, care în această zonă curge foarte lent formând bălţi largi (în dreptul sitului lăţimea bălţii depăşeşte $50 \mathrm{~m}$ ). Cotele altimetrice ale promontoriului sunt cuprinse între $85 \mathrm{~m}$ şi $96 \mathrm{~m}^{11}$, iar suprafaţa acestuia este de aproximativ 20,8 ha. (planşele $2,4)$.

\section{Scurt istoric al cercetărilor în zona văii Cociovaliștei}

În ceea ce priveşte potenţialul arheologic al zonci Săftica-Baloteşti acesta este relativ bine cunoscut în literatura de specialitate încă din anii ' 80 , atât ca urmare a efectuării unor periegheze desfaşurate în această zonă cu ocazia unor preconizate lucrări de îmbunătăţiri lunciare sau mai recent, dar probabil şi în urma reactualizării PUG Baloteşti (1998) sau al claborării şi avizării PUG Baloteşti (20072008). Astfel, de-a lungul văii Cociovaliştei (Pociovaliştei), în actualul teritoriu administrativ al localitătilor Corbeanca, Săftica, Balotești, Căciulaţi, Moara Vlăsiei şi Grădiştea sunt cunoscute peste 30 de semnalări (planşa 3) ale unor situri arheologice (în special aşezări), datând din perioade istorice diverse (preistoric: epoca neolitică - c. Gumelniţa, epoca bronzului - c. Tei; perioada Latène: sec. III-I a. Chr. şi sec. I-III p. Chr.; perioada post-romană: sec. II-IV p. Chr. (c.

\footnotetext{
${ }^{10}$ Sandu 1992. 289.

11 Plan de reléeinlă altimetricã Marea Neagrã 1975.
}

Chilia-Militari); perioada medievală timpurie: sec. V-VII şi sec. VIII-X şi perioada feudală $)^{12}$. Cele mai apropiate zone cu potenţial arheologic cunoscut şi reperat, raportat la arealul cercetat, sunt cele din perimetrul unor situri arheologice, clasate în Lista Monumentelor Istorice (2004) ${ }^{13}$. Acestora li se adaugá o serie de descoperiri arheologice mai vechi şi mai recente din zona de nord a județului Ilfov ${ }^{14}$, respectiv din perimetrul comunelor Balotești, Ciolpani, Corbeanca, Grădiștea, Gruiu, Moara Vlăsiei, Periş, Snagov, respectiv de pe văile Lacul Mănăstirii (Bălteni), Ialomiţei, Snagovului, Vlăsiei, Mostiştei.

În cursul ultimelor trei decenii, multe dintre acestea au fost însă semnificativ afectate în contextul evoluţiei teritoriului urban al municipiului Bucureşti, al localităţilor limitrofe capitalei din zona de nord-nord-est a judeţului Ilfov, dar şi de marile lucrări de amenajare a teritoriului din perioada comunistă ${ }^{15}$. Unul dintre cele mai elocvente cazuri privind existenţa unui potenţialul arheologic semnificativ de-a lungul văilor din această regiune este indiscutabil cel al văii Mostiştei ${ }^{16}$.

În ultimul deceniu însă, cel mai semnificativ impact asupra vestigiilor arheologice existente în acest areal, inclusiv cele din zona văii Cociovalişte se datorează dezvoltărilor considerabile ale ariilor rezidenţiale din extravilanul localităţii Baloteşti (şi nu numai), aceasta fiind în fapt o caracteristică pentru toată zona situată în nordul judef̧ului Ilfov. O analiză preliminară efectuată pe o serie de imagini aeriene şi satelitare ale zonei de referinţă pentru acest studiu înfăţişează ritmul accelerat al acestor dezvoltări în ultimii 3 ani, inclusiv în perimetrul unor situri arheologice reperate (planşa 5). Tinând cont de absenţa cvasi-totală a unor noi informaţii (semnalări, rapoarte arheologice preliminare) în literatura de

\footnotetext{
${ }^{12}$ Sandu 1992, 309-319.

13 Lista Monumentelor Istorice 2004. publicatã în Monitorul Oficial nr. 646 bis din 16 iulie 2004, vol. II, $1570-1572$.

${ }^{14}$ Sandu 1992, 289-323.

${ }^{15}$ Sandu 1992, 309-319; PUG Baloteşti (2008).

${ }^{16}$ Şerbănescu. Trohani 1978; Trohani 1988.
} 
specialitate recentă (în special în Cronica Cercetărilor Arheologice din România) sau în baza de date referitoare la evidenţa cercetărilor arheologice din România ${ }^{17}$, există premise care îndreptăţesc luarea în calcul a ipotezei potrivit căreia în situaţia marii majorităţi a proiectelor de dezvoltare rezidenţială să nu fi fost luate în considerare măsuri minimale pentru înregistrarea şi documentarea vestigiilor arheologice ce vor fi existat în aceste perimetre, în ciuda faptului că încă din anul 2000 a fost adoptată o legislaţic clară în domeniu.

Coroborarea datelor cunoscute din literatura de specialitate, modelarea tridimensională a spaţiului aflat în imediata vecinătate a sitului cercetat (planşa 2), dar şi analiza preliminară a imaginilor aeriene oferă argumente pertinente, credem, pentru ca în viitor, pornind de la acest studiu de caz, autorităţile centrale şi locale cu competență în domeniu să acorde o atenţie sporită efectuării cercetărilor arheologice în zonele adiacente văilor Cociovaliştei, Vlăsiei, lalomitei şi lacurilor Snagov sau Căldăruşani, în aria de nord a jud. Ilfov. Aşa cum va fi prezentat în cele ce urmează, rezultatele cercetărilor arheologice preventive din acest punct arată că foarte probabil -în zonele situate de-a lungul acestor cursuri de apăeste vorba de o locuire sezonieră, însă cartarea unor atare descoperiri poate să determine o reinterpretare în ceea ce priveşte intensitatea locuirii umane de-a lungul perioadelor istorice în acest areal.

\section{Consideraţii de ordin metodologic}

Proprietatea în perimetrul căreia s-a făcut cercetarea a avut suprafataa ${ }^{18}$ de aproximativ $30.000 \mathrm{~m}^{2}$. Proiectarea şi trasarea sondajelor şi secţiunilor arheologice a ţinut cont de configuraţia terenului, jumătatea de est a promontoriului având pantele orientate pe direcţia est-vest, ceea ce a determinat ca toate sondajele din etapa evaluare să aibă o orientare clară pe această axă.

\footnotetext{
17 ACERA - Sistemul de Administrare a Cercetărilor Arheologice din România. disponibil pentru consultare on-line la adresa hitp://arl. cimec.ro/.

18 Suprafą̧a exactā fïind de $29.900 \mathrm{~m}^{2}$, din care aproximativ $5.400 \mathrm{~m}^{2}$ reprezentând malul Cociovaliştei. teren proaspăl curāial de arbuşti.
}

Evaluarea de teren a fost realizată prin două metode distincte de investigarea, respectiv prin periegheză şi sondare, fiind efectuată în prima jumătate a lunii octombrie 2008.

Periegheza a fost efectuată în scopul observării unor indicii preliminare care să confirme potenţialului arheologic al perimetrului ce urma a fi afectat de viitoarele construcţii.

Sondarea a fost realizată prin deschiderea a 117 unităţi de săpătură (sondaje) distribuite uniform pe suprafaţa parcelei (planşa 6). Dimensiunile acestora au fost variabile, fiind cuprinse între $1,80 \times 1,0 \mathrm{~m}$ şi $8,0 \times 1,0 \mathrm{~m}$. Aceste sondaje au avut scopul de a stabili eventualele intervenţii antropice (de interes istorico-arheologic) din perimetrul promontoriului în discufie. Realizarea sondajelor s-a făcută sub supraveghere arheologică, fiind folosit un utilaj mecanic (buldoexcavator), efectuându-se o serie de observaţii preliminare de ordin stratigrafic, dar şi delimitarea perimetrului cu potenţial arheologic cert.

Ulterior, în etapa propriu-zisă de cercetare arheologică preventivă, acest perimetru a fost investigat prin deschiderea unor unităţi de săpătură având ca scop stabilirea existenţei și distribuţiei eventualelor intervenţii antropice (de interes istorico-arheologic) în această zonă, respectiv investigarea exhaustivă a vestigiilor arheologice identificate preliminar. Astfel, săpăturile arheologice cu caracter preventiv au impus realizarea — pe două axe longitudinale, ce străbat proprietatea aproximativ de la nord la sud și de la vest la est, cu localizare în partea de SSE a terenului în discuţie- a 9 suprafeţe şi secţiuni de cercetare, cu dimensiuni şi orientări variabile (planşele 6, 7). Secţiunile trasate în zona delimitată ca fiind zonă cu potenţial arheologic cert au însumat o suprafaţă totală de $1.291 \mathrm{~m}^{2}$.

Pentru toate etapele cercetării au fost realizate măsurători topografice de detaliu. În ceea ce privește modalitatea de înregistrare a observaţiilor efectuate în cadrul derulării săpăturii, au fost utilizate metode descriptive uzuale în arheologie, respectiv însemnările de teren (în format standard - fişe de secţiune, 
fişe de complex, dar şi alte înregistrări de tip text). Metodele de înregistrare grafică constau în realizarea de planuri şi profile, cât şi a unor fotografii în format digital. Înregistrarea stratigrafiei verticale s-a realizat contextual.

\section{Scurtă descriere a unităţilor de săpătură}

Studiul diverselor surse de arhivă şi unele dintre sondajele efectuate pe teren au permis delimitarea unui anumit perimetru cu potenţial arheologic (fragmentele ceramice descoperite incadrându-se exclusiv în perioada secolelor II-I a. Chr.), fiind astfel confirmată parțial informaţia existentã în Lista Monumentelor Istorice din judeţul Ilfov (2004), care plasează pe malul drept al pârâului Cociovalişte, în raza com. Baloteşti un sit arheologic de categoria B (importanţă locală) cu vestigii din perioada epocii bronzului şi epoca getodacică. Sondajele au fost efectuate pe nouă aliniamente orientate est-vest, acoperindu-se într-o manieră uniformă întreaga proprietate, acordându-se atenţie sporită zonele în care a fost semnalată existenţa unor artefacte. În vederea delimitării certe a zonei cu potenţial arheologic s-au dovedit a fi relevante observaţiile şi descoperirile efectuate în cazul a zece sondaje (S023, S025, S108, S109, S1 10, S033, S035, S053, S055, S056), toate acestea fiind grupate în zona de sud-sud-est a perimetrului investigat prin cercetări arheologice preventive.

În urma efectuării evaluării teoretice şi de teren, a putut fi delimitată o zonă cu potenţial arheologic, aici fiind deschise alte 9 unităţi de săpătură (secţiuni şi suprafețe), descrise în cele ce urmează. (planşa 7)

S I - orientare aproximativă NE-SV, cu dimensiuni de $110 \times 2 \mathrm{~m}$; secţiune magistrală necesară verificării stratigrafiei în zona supusă investigaţiei. În cadrul acesteia au fost descoperite numeroase fragmente ceramice aflate în poziţie secundară, într-un sediment de culoare cenuşie, discontinuu. În carourile 34-35 a fost descoperită partea inferioară a unei gropi, complex arheologic notat Cpl 3. (planşa 9.3.)
S II - orientare aproximativă NE-SV, cu dimensiuni de $25 \times 5 \mathrm{~m}$; situată paralel cu S I şi despărţită de aceasta printr-un martor stratigrafic cu o lăţime de $0,30 \mathrm{~m}$. Secţiunea a inclus în partea sa de SE sondajul S035 (deschis în etapa de evaluare de teren). În această secţiune a fost identificat şi cercetat un complex arheologic (groapă), notat Cpl 1. (planşele 9.1., 10)

S III - orientare aproximativă NE-SV, cu dimensiuni de $8,5 \times 5 \mathrm{~m}$; situată paralel cu S I şi despărţită de aceasta printr-un martor stratigrafic cu o lăţime de $1,50 \mathrm{~m}$. Sectiunea a inclus în jumătatea sa estică sondajul $\mathrm{S} 055$ (deschis în etapa de evaluare de teren). Concentrarea de fragmente ceramice observată - inclusiv în timpul efectuării sondajelor de evaluare- într-un sediment de culoare negrucenuşiu, aparţinea unei gropi de mari dimensiuni, complex arheologic notat $\mathrm{Cpl} 2$. (planşele 9.2., 11)

S IV - orientare aproximativă NV-SE, cu dimensiuni de $30 \times 3 \mathrm{~m}$; situată paralel cu S III, S VII şi S IX, respectiv perpendicular pe S I şi despărţită de acestea prin martori stratigrafici cu o lăţime de $1 \mathrm{~m}$. Secţiunea a inclus sondajul S108, deschis în etapa de evaluare de teren.

S V - orientare aproximativă NE-SV, cu dimensiuni de $12 \times 5 \mathrm{~m}$; situată paralel cu S I şi S III, despărţită de aceasta prin martori stratigrafici cu o lăţime de $1 \mathrm{~m}$ lăţime.

S VI - orientare aproximativă NE-SV, cu dimensiuni de $10 \times 6 \mathrm{~m}$; situată paralel cu S II şi despărţită de aceasta printr-un martor stratigrafic cu o lăţime de $1 \mathrm{~m}$. În sedimentul de culoare cenuşie (vezi mai jos descrierea stratigrafiei) a fost descoperită o lamă de cuţit fragmentară, aflată în poziţie secundară.

S VII - orientare aproximativă NV-SE, cu dimensiuni de $22 \times 11 \mathrm{~m}$; situată paralel cu S IV şi despărţită de aceasta printr-un martor stratigrafic cu o lăţime de $1 \mathrm{~m}$. Secţiunea a inclus sondajul S 008, deschis în etapa de evaluare de teren.

S VIII - orientare aproximativă NV-SE, cu dimensiuni de $15 \times 10 \mathrm{~m}$; situată paralel cu S IV. 
S IX - orientare aproximativă NV-SE, cu dimensiuni de $15 \times 10 \mathrm{~m}$; situată paralel cu S IV.

\section{Stratigrafia generală a zonei cercetate}

Stratigrafia verticală a zonei — aşa cum a fost stabilită încă din etapa evaluării de terennu a fost una complexă, în cele mai multe situaţii observate fiind identificate doar trei unităţi stratigrafice:

- u.s. 1000 - nivelul vegetal actual, de culoare neagră-cafenie, grad de compactare scăzut, granulaţie ridicată, saturat, permeabil, cu foarte puţine materiale contemporane remaniate, rar şi materiale arheologice;

- u.s.1001 - strat de argilă, de culoare galbenă, compact, omogen, permeabil, ce conţine carbonaţi, aparţinând bazei terasei; acesta reprezintă nivelul nominalizat de arheologi cu titulatura de steril arheologic;

- u.s.1002 - nivel siltic, de culoare albgălbie, omogen, grad de compactare scăzut, permeabil, saturat mediu.

În cadrul etapei de cercetare arheologică preventivă stratigrafia verticală ${ }^{19}$ a sitului şi implicit a complexelor identificate s-a făcut contextual şi anume au fost definite următoarele niveluri (planşele 10,11):

Context 1 - nivelul vegetal actual, de culoare brun cenuşiu închis (negru), cu textură siltică (prăfoasă) nisipoasă, structură agregată datorată bioturbaţiei faunei, grad de compactare scăzut, frecvente rădăcini actuale şi urme de rădăcini, permeabil, cu foarte puţine materiale contemporane remaniate, rar şi materiale arheologice, grosime de cca. $0,30 \mathrm{~m}$;

Context 2 - nivel antropic, discontinuu, sediment de culoare cenuşiu mediu, textură siltică nisipoasă, structură granulară, omogen, compact, conţine fragmente ceramice de mici dimensiuni, oase, pigmenţi de cărbune, bucăţele de chirpici în poziţie secundară, grosime de cca. $0,25 \mathrm{~m}$;

\footnotetext{
19 Autorii mulţumesc şi pe aceastã cale colegului lor dr. Constantin Haită pentru informațiile puse la dispoziţie şi observaţiile de ordin sedimentologic efectuate în ceea ce priveşte stratigrafia sitului cercetat.
}

Context 3 - strat de argilă, de culoare galbenă, compact, omogen, permeabil, ce conţine carbonaţi, aparţinând bazei terasei; acesta reprezintã nivelul identificat de arheologi drept „steril arheologic”, grosime de cca. $0,30 \mathrm{~m}$;

Context 4 - sediment de culoare neagrăcenuşie, textură siltică nisipoasă, structură granulară, relativ eterogenă, constituind umplutura complexelor arheologice; conţine fragmente ceramice, oase, pigmenţi de cărbune, fragmente de vatră şi chirpici, grosime de cca. 0,55-1,20 m;

Context 5 - sediment de culoare cafenie, compact, omogen, conţinând puţine fragmente ceramice şi reprezentând o lentilă rezultat al eroziunii accentuate şi acumulării;

Context 6 - nivelul steril, sediment de culoare alb-gălbuie, siltic, friabil, conţine carbonaţi şi este echivalent din punct de vedere arheologic contextului nr. 3, din punct de vedere stratigrafic fiind situat sub acesta, grosime de cca. $0,20 \mathrm{~m}$.

Context 7 - sediment de culoare cafenie-gălbui, siltic, friabil, cu pigmenţi de argilă galbenă şi echivalent ca textură şi compoziţie contexelor 3 şi 6 .

Caracteristicile generale ale stratigrafiei geologice stabilite în urma sondajelor efectuate indică existenţa unor intervenţii antropice moderne-contemporane în zonă, de tipul amenajărilor, îndreptărilor, nivelărilor etc. deoarece nivelul vegetal actual (u.s.1000) nu poate suprapune direct stratul de argilă al terasei (u.s.1001). De asemenea, variaţiile privind grosimea nivelului vegetal (u.s.1000) şi raportul altimetric al acestuia cu stratul de argilă din baza terasei (u.s.1001), demonstrează fără nici un fel de dubiu intervenţiile antropice menţionate mai sus. Având în vedere faptul că terenul vizat de investigaţia de faţă a servit anterior unor scopuri agricole, intervenţiile antropice au fost realizate cel mai probabil- în vederea amenajării acestuia pentru cultivare.

În altă ordine de idei, în unele sondaje (S023, S025, S033, S035, S053, S055, S056, S108-110), dar şi în unele suprafețe de 
cercetare (S II, S III şi S VI) a fost surprins un nivel cenuşiu, cu material arheologice (lentile de chirpici ars, fragmente ceramice, bucăţele de cărbune), notat u.s.1003 (echivalent cu contextele 2 şi 4). Caracteristicile sedimentare ale acestuia sunt următoarele: culoare cenuşie, grad de compactare mediu, omogen, saturat, permeabil. Acesta reprezintă un paleosol ${ }^{20}$ şi este suprapus în partea superioară de nivelul vegetal actual (u.s.1000), fiind amplasat deasupra nivelului de argilă din baza terasei (u.s. 1001). Din acest nivel (u.s.1003) pornesc şi complexele arheologice identificate şi cercetare (Cpl l-3). Nu este exclusă posibilitatea ca în sondajele în care nu a fost identificat, acesta să fi fost distrus/îndepărtat de lucrările de amenajare amintite anterior, inclusiv de lucrările de nivelare efectuate anterior în urma desfiintării livezii care a existat aici.

Din punct de vedere al stratigrafiei orizontale, caracterul cercetărilor de evaluare efectuate pe terenul în discuţie nu au permis realizarea prea multor observaţii în acest sens. În primul rând, sondajele arheologice au fost de dimensiuni variate, amplasarea acestora fiind realizată la distanţe relativ mari (planşa 6), în scopul de a verifica o suprafată cât mai reprezentativă din terenul supus evaluării. Această situaţie nu a permis obţinerea unor profile care să stabilească relaţiile pe orizontală dintre complexele/contextele arheologice identificate. Datele referitoare de stratigrafia orizontală au fost completate prin efectuarea cercetărilor arheologice preventive, observaţiile realizate în acest context indicând o distribuţie spaţială a complexele/contextele arheologice, aparent uniformă, cu o concentrate evidentă în partea de SSE al terenului, respectiv spre malul apei.

\section{Scurtă descriere a complexelor arheologice \\ Groapa nr. 1 (Cpl. 1) (planşele 9.1.,} 10). Groapă de formă ovală, cu diametrul de $2,30 \mathrm{~m}$, albiată în secţiune şi având adâncimea maximă păstrată de aproximativ $0,55 \mathrm{~m}$.

\footnotetext{
${ }^{20}$ Mai precis nivelul arheologic sau stratul de cultură conlorm terminologiei utilizate de arheologi.
}

Complexul este săpat într-un sediment (context 3) de culoare galbenā (argilă siltică), umplutura (context 4) acestuia fiind constituită dintr-un sediment de culoare negru-cenuşiu, care conţinea fragmente ceramice, oase, pigmenţi de cărbune, plăcuţe de vatră.

Materialul arheologic este reprezentat de vase borcan, fragmente de fructieră, torţi şi fragmente din corpul unor amfore, căni, platouri, dar şi sârmă din cupru (?).

Groapa nr. 2 (Cpl. 2) (planşele 9.2., 11). Groapă de formă ovală în plan, cu diametrul de $3,50 \mathrm{~m}$, având în secţiune formă de clopot, colmatată şi prezentând mai multe nivele de umplere succesivă. Baza gropii avea formă tronconică, adâncimea maximă păstrată fiind de $0,55 \mathrm{~m}$. Umplutura gropii conţinea două momente de umplere şi lentile de pământ mixt datorate perioadelor de eroziune şi acumulare. Groapa a fost secţionată pe axa N $S$ pentru stabilirea stratigrafiei verticale (planşa 11). Nivelul de săpare a gropii a fost identificat parţial. Complexul a fost săpat într-un sediment de culoare brun-gălbuie, compact, argilos (context 3) şi se adâncea într-un sediment de culoare alb-gălbuie (context 6), nisipos, friabil, cu foarte mulţi carbonaţi. Au putut fi observate în plan vertical o serie de elemente, precum baza gropii (având formă cilindrică), nivelurile de umplere succesivă (inclusiv datorate abandonului - context 4), eroziunea/colmatarea pereţilor pe laturile de sud şi nord (context 5). Conturul gropii a fost identificat în plan orizontal, acesta fiind de formă aproximativ circulară, fără a putea fi observate perturbări.

Primul nivel de umplere al gropii îl reprezintă contextul 5, care este constituit dintr-un sediment de culoare cafeniucenuşie,eterogen, friabil, cu mulţi carbonaţi, conţine puţine fragmente ceramice.

Al doilea nivel de umplere (context 4) este constituit dintr-un sediment de culoare negru-cenuşiu, conţine fragmente ceramice, oase animale prezentând urme de ardere, pigmenţi de cenuşă, chirpici ars.

Scopul realizării gropii este greu de stabilit, funcţionalitatea posibilă a gropii fuind 
-cel mai probabil - cea de tip siloz, respectiv pentru depozitarea produselor în vrac. Aceasta pare să fi fost utilizată pentru o scurtă durată sau dezafectată şi abandonată. Abandonul acesteia a determinat fenomene de eroziune accentuatã (context 5) şi acumulare (context 4), în ultima ei fază.

Groapa nr. 3 (Cpl. 3) (planşa 9.3.). Partea inferioară a unei gropi, în care se păstrau o serie de fragmente ceramice descoperite in situ aparţinând unui vas borcan întregibil. Complexul a fost afectat semnificativ de lucrările agricole efectuate în anii ' 80 .

\section{Materialul ceramic}

Materialul ceramic descoperit in aceste complexe este alcătuit din tipuri de vase modelate cu mâna sau lucrate la roată, care aparţin perioadei geto-dace clasice. Materialul este fragmentar, vasele descoperite fiind neîntregibile. Totuşi formele acestora au putut fi reconstituite, fiind vorba de fructiere sau vase borcan, căni, platouri, fragmente aparţinând unor vase de provizii, torţi şi fragmente din corpul unor amfore. Pasta predominantă este grosieră având ca degresant pietricele, nisip, fragmente vegetale; aceasta este arsă oxidant (culoare cărămizie) sau reducător (culoare cenuşie). Vasele realizate din pastă fină sunt reprezentate de vasele de tip fructieră şi câteva fragmente (de bază perforată) ce aparţin unor strecurători. Astfel, principalele tipuri de vase descoperite cu ocazia acestor cercetări arheologice preventive sunt:

Vasul borcan prevăzut cu butoni cilindrici, apucători, bază dreaptă, decorat cu brâu alveolar, impresiuni digitale, linii incizate. Analogii: Crişan 1969, 161-163, pl. LXXIII/1-6, LXXV/3-6, 9 (categoria de ceramică rudimentară încadrată în faza a III-a clasică de către I. H. Crişan); Trohani 1997, 212-213, pl. XXIV/1, 3-4, pl. XXV.

Cana prezentă doar prin torţi fragmentare, cu secţiune rotundă sau ovală şi baze inelare. Analogii: Crișan 1969, 165-166, pl. LXII; Trohani 2000, 387/fig. 10, 388/fig. 11.
Cupa reprezentată numai prin fragmente aparţinând corpului conic şi buzei. Analogii: Trohani 2000, 389/fig. 19/4-8.

Fructiera este atestată numai sub forma unor fragmente ce aparţin corpului tronconic şi părţii inferioare (piciorul), partea superioară fiind reprezentată de buze arcuite orizontal sau faţetate. Analogii: Crişan 1969, 167-168, pl. L/1-6, tipul IV (sec. I a. Chr.); 168-170, pl. LIV/1-4, 7 (sec. I p. Chr.); Trohani 2000, 389390, fig. 12, 13.

Strecurătoarea prezentă numai prin fragmente aparţinând corpului conic, semiferic, perforat. Analogii: Crişan 1969, 171, fig. 85, pl. LVI/2; Trohani 2000, 396, fig. $17 / 1$.

Castronul de formă tronconică, cu diametru mare la partea superioară şi baza dreaptă. Analogii: Crişan 1969, p. 179-180, pl. LXXXI, LXXXII/ tipul I; Trohani 2000, p. 392, fig. $15 / 2,3-7$; p. 393, fig. $16 / 1,2-6$.

Bolul atestat numai prin fragmente aparţinând corpului semisferic şi buzei. Analogii: Trohani 2000, 399, fig. 19/4-8.

Ulciorul reprezentat prin fragmente aparținând bazelor inelare şi buzelor verticale. Analogii: Crişan 1969, 127, fig. 87, pl. LVIII (ulcioare cu o toartă).

Amfora este reprezentată de două fragmente. Pe baza morfologiei şi a analizei vizuale a pastei celor două fragmente amfore, au putut fi stabilite analogii în rândul celor descoperite la Popești (jud. Giurgiu) ${ }^{21}$. Cele două fragmente descoperite recent la Baloteşti datează —cel mai probabil- din sec. II a. $\mathrm{Chr}^{22}$

Analiza întregului lor de material ceramic descoperit cu prilejul cercetărilor arheologice preventive din cadrul sitului

\footnotetext{
${ }^{21}$ Mostre din cele două amfore descoperite la Balotești. împreună cu câteva din cele prelevate de la Popeşti, vor face obiectul unei analize petrogralice (David Williams). ${ }_{22}$ Autorii mulţumesc şi pe aceastã cale dr. Andrei Opait pentru determinarea acestor fragmente de amfore. Rezultatele analizelor petrografice vor fi publicate de către Andrei Opaịt într-un studiu dedicat amforelor produse local.
} 
Balotești - Flower City permite o încadrare din punct de vedere cronologic a acestuia în perioada Latène (sec. II-I a. Chr.) ${ }^{23}$.

Starea de conservare a complexelor arheologice, dar nici contextele certe ale acestora nu au fost de asemenea natură încât să permită stabilirea unor relaţii între cele 3 gropi cercetate. Astfel nu există posibilitatea de a determina mai precis modul de asociere al complexelor sau posibilele etape de evoluţie şi durata locuirii. Acest termen este folosit în sens convenţional, datele existente în stadiul actual al cercetării nepermiţând încadrarea întro anumită categorie de sit a complexelor identificate (gropi a căror parte superioară a fost afectată semnificativ de activităţi antropice de dată recentă). Totuşi, structura şi inventarul acestora, coroborate cu concluziile studiului resturilor de faună (vezi infra), permit o încadrare generală în categoria aşezărilor.

Dincolo de confirmarea existenţei potenţialului arheologic şi revizuirea unor consideraf̧ii de ordin cronologic în legătură cu materialul descoperit în cadrul sitului, cercetarea de fałă a creat premisele unei abordări pluridisciplinare, dacă este să ne raportăm la analiza geo-spaţială privind amplasamentul sitului în mediul ambiant şi peisajul înconjurător. Modelul digital al sectorului văii Cociovaliştei din imediata vecinătate a sitului de la Baloteşti - Flower City (planşa 4), dar şi cartarea unor alte puncte de interes arheologic din apropiere - semnalate anterior în literatura de specialitate- sunt de natură să ofere o altă perspectivă asupra locuirii umane din acest habitat în perioadele pre- şi protoistorice. Astfel cercetarea arheologică preventivă nu determină exclusiv investigarea prin metode intruzive a perimetrului care urmează a fi afectat de lucrări de construire, ci şi studierea — printr-o serie întreagă de metode non-intruzive- vestigiilor în raport cu incadrarea lor în peisaj ${ }^{2-4}$, contribuind astfel la o

\footnotetext{
23. Autorii mulumesc sii pe accastă cale colegului lor dr. George Trohani pentru observatiile sii sugestiile formulate în legătură cu malerialului ceramic descoperit în cadrul sitului cle la Baloteşti.

24 Johnson 2005. 156-159.
}

mai bună înţelegere a caracteristicilor şi semnificaţiei unui anumit sit.

\section{CATALOGUL DESCOPERIRILOR ${ }^{25}$} (planşele 12-2926)

\section{GROAPA NR. 1 (Cpl. 1) (planşele 12-16)}

\section{Fructiere}

1. Fructieră (fragmentară); dg $=24 \mathrm{~cm}$. Pastă de culoare cărămizie (2,5 YR 5/6), cu particule de nisip, mică şi pietricele; ardere oxidantã; modelat cu mâna. Buza arcuită orizontal, cu marginea rotunjită. (nr. inv. t. 1)

2. Fructieră (fragmentară); dg $=18 \mathrm{~cm} ; \mathrm{dm}=25,4$ $\mathrm{cm}$. Pastă de culoare cărămiziu-cenuşie la exterior şi neagră la interior (7.5 YR; 6/6), cu particule de nisip şi pietricele; ardere oxidantă neuniformă; prelucrat la roată. Buza arcuită orizontal, marginea rotunjită. (nr. inv. t. 2)

3. Fructieră (fragmentară); $d g=15 \mathrm{~cm} ; \mathrm{db}=10,6$ $\mathrm{cm} ; \mathrm{hp}=15 \mathrm{~cm}$. Pastă de culoare cărămizie $(7,5 \mathrm{YR}$ 7/8), cu particule de nisip, mică şi pietricele; ardere oxidantă; prelucrat la roată. Se păstrează piciorul şi fragmente din corp. Piciorul vasului este scurt, inelar la bază, cu o canelură circulară. (nr. inv. t. 3)

Oale borcan/vase "pântecoase"

4. Oală borcan (fragmentară). Pastă de culoare cărămizie $(2,5$ YR 6/8), cu particule de nisip, pietricele şi urme vegetale; arderea oxidantă; modelat cu mâna. Fragmentul ceramic păstrează unul din butoni şi o parte din brâul alveolar. (nr. inv. t. 4)

5. Oală borcan (fragmentară). Pastă de culoare cărămizie $(2,5$ YR 6/8), cu particule de nisip, pietricele şi urme vegetale; ardere oxidantă; modelat cu mâna. Decorat cu brâul alveolar. (nr. inv. t. 5)

6. Oală borcan (fragmentară). Pastă de culoare cărămizie (2,5 YR 5/8), cu particule de nisip, pietricele şi urme vegetale; ardere oxidantă; modelat cu mâna. Decorat cu brâul alveolar. (nr. inv. t. 6)

7. Oală borcan (fragmentară); $d b=14 \mathrm{~cm}$. Pastă de culoare cărămizie (Gley 13/10Y), cu particule de

\footnotetext{
25 Abrevierile utilizate: $d b=$ diametru bazā, $d g=$ diametru gură. $\mathrm{dm}=$ diametru maxim, do $=$ diametru oriliciu, $\mathrm{dt}=$ diametru toartă, $\mathrm{g} .=$ grosime. $\mathrm{hp}=$ înălţime păstratā. Lp = lungime pāstrată, !p = lăţime păstrată: nr. inv. $\mathrm{l}$. = număr inventar tranzit.

26 Autorii mulţumesc şi pe aceastã cale colegei lor Georgiana Ducman pentru realizarea desenelor materialul arheologic descoperit în cadrul sitului de la Baloteşti Flower City.
} 
nisip, pietricele şi urme vegetale; ardere oxidantă; modelat cu mâna. Baza dreaptă. (nr. inv. t. 7)

8. Oală borcan (fragmentară). Pastă de culoare cărămizie $(2,5$ YR 5/8), cu particule de nisip, pietricele şi urme vegetale; ardere oxidantă; modelat cu mâna. Decorat cu brâul alveolar şi incizii verticale realizate cu pieptănul. (nr. inv. t. 8)

9. Oală borcan (fragmentară); db $=9 \mathrm{~cm}$. Pastă grosieră, de culoare cărămizie $(2,5 Y R \quad 6 / 6) \mathrm{cu}$ particule de nisip, pietricele şi urme vegetale; ardere oxidantă; modelat cu mâna. Baza dreaptă. (nr. inv. t. 9)

10. Vas "pântecos" (fragmentar); $\mathrm{dg}=21 \mathrm{~cm}$. Pastă de culoare cărămizie $(2,5 Y R$ 6/6) cu particule de nisip, pietricele şi urme vegetale; ardere oxidantă; modelat cu mâna. Buza vasului răsfrântã şi teşită oblic în exterior. (nr. inv. t. 10)

11. Oală (fragmentară); dg $=21 \mathrm{~cm}$. Pasta de culoare cărămizie (5YR 7/6), cu particule de nisip, mică, pietricele şi urme vegetale; ardere oxidantă, neuniformă; modelat cu mâna. Buza uşor arcuită, margine rotunjită, sub aceasta fiind prinsă o toartă rotundă în secţiune. (nr. inv. t. 11)

\section{Căni / cupe}

12. Cupă (?) (fragmentară); dg = $10 \mathrm{~cm}$. Pastă grosieră, de culoare brun-cenuşie (2YR 6/4), cu particule de nisip, pietricele şi urme vegetale; ardere oxidantă; modelat cu mâna. Buza răsfrântă, cu marginea rotunjită. (nr. inv. t. 12)

13. Cupă (?) (fragmentară); db $=8 \mathrm{~cm}$. Pastă de culoare cărămizie $(7,5$ YR 5/6), cu particule de nisip şi pietricele; ardere oxidantă; modelat cu mâna. Baza vasului este dreaptă. (nr. inv. t. 13)

14. Cană (?) (fragmentară). Pastă fină, de culoare cenuşie (Gley 2 5/5BG), cu particule de nisip și mică; ardere reducătoare; prelucrat la roată. Fragmentul ceramic prezintă opt incizii realizate cu ajutorul pieptănului. (nr. inv. t. 14)

\section{Castroane / boluri}

15. Castron (fragmentar); $d g=33 \mathrm{~cm}$. Pastă de culoare cărămiziu-cenuşie ( 5 YR 6/8), cu particule de nisip şi pietricele; ardere reducătoare; modelat cu mâna. Buza arcuită, răsfrântă, cu marginile rotunjite. (nr. inv. t. 15)

16. Castron (fragmentar); $d g=21 \mathrm{~cm}$. Pastă fină, de culoare cărămizie $(2,5 \mathrm{YR} 6 / 8)$, cu particule de nisip; ardere oxidantã; prelucrat la roată. Buza răsfrântă, scurtă. (nr. inv. t. 16)

17. Castron (fragmentar); $d g=21 \mathrm{~cm}$. Pastă fină, de culoare cenuşie (Gleyl 7/10Y), cu particule de nisip; ardere reducătoare; lucrat la roată. Buza arcuită orizontal. (nr. inv. t. 17)
18. Castron (fragmentar); $d g=20 \mathrm{~cm}$. Pastă fină, de culoare cenuşie (10YR 6/4), cu particule de nisip, mică şi oxizi de fier; ardere reducătoare; prelucrat la roată. Buza uşor oblică, marginea rotunjită. (nr. inv. t. 18)

19. Castron (fragmentar); dg $=20 \mathrm{~cm}$. Pastă semifină, de culoare cenuşie (Gley 1 7/10 GY), cu particule de nisip, ardere reducătoare, modelat cu mâna. Buza orizontală, faţetată. (nr. inv. t. 19)

20. Bol (fragmentar); $d g=12 \mathrm{~cm}$. Pastă de culoare neagră (Gley $12,5 / \mathrm{N}$ ), cu particule de nisip, pietricele şi urme vegetale; ardere reducătoare; modelat cu mâna. Buza orizontală, marginea rotunjită. (nr. inv. t. 20)

\section{Ulcioare}

21. Ulcior (fragmentar); db $=8 \mathrm{~cm}$. Pastă semifină, de culoare cenuşie, (6/5B Gley 2$)$, cu particule de nisip, pietricele; ardere reducătoare; prelucrat la roată. Baza inelară, profilatură externă uşor pronuntată. (nr. inv. t. 21)

\section{Incerte}

22. Strecurătoare (?) (fragmentară); dg $=7 \mathrm{~cm}$. Pastă fină, de culoare cenuşie (Gley 1 6/10Y), cu particule de nisip; ardere reducătoare; prelucrat la roată. Buza rotunjită, arcuită în exterior, prezintă o canelură uşoară ce o desparte de corp. (nr. inv. t. 22)

23. Fragment ceramic (ulcior ?). Pastă semifină, de culoare cenuşie, (6/10B; Gley 2), cu particule de nisip şi pietricele; ardere reducătoare; prelucrat la roată. Decorat cu incizii realizate cu ajutorul pieptănului. (nr. inv. t. 23)

24. Bază vas (cană ?); db=12 cm. Pastă de culoare cenuşie (10Y; 5/5B, Gley 2), cu particule de nisip; ardere reducătoare; prelucrat la roată. Baza de formă inelară. (nr. inv. t. 24)

\section{Obiect de metal}

25. Sârmă din bronz (fragmentară); $L=3,6 \mathrm{~cm} ; \mathrm{I}=$ $2,2 \mathrm{~cm}$. (nr. inv. t. 98)

GROAPA NR. 2 (Cpl. 2) (planşele 17-26)

\section{Obiect de metal}

26. Cuţit; lamă fragmentară; $L p=3,7 \mathrm{~cm}, I=1,2$ $\mathrm{cm}, \mathrm{g} .=0,3 \mathrm{~cm}$. (nr. inv. t. 99)

\section{Fusaiolă}

27. Fusaiolă; $\mathrm{dm}=4,3 \mathrm{~cm} ; \mathrm{do}=1 \mathrm{~cm} ; \mathrm{h}=2,8 \mathrm{~cm}$. Pastã de culoare cărămizie (5YR 5/8), cu particule de nisip şi pietricele; ardere oxidantă şi urme de ardere secundară; formă bitronconică. (nr. inv. t. 97) 


\section{Amfore}

28. Amforă (fragment din toartă şi perete); $L p=5,8$ $\mathrm{cm}$. Pastă fină (7.5YR 7,5/6). Toartă aproximativ dreptunghilară în secţiune, cu dimensiuni de $3,4 \times$ $2,3 \mathrm{~cm}$. (nr. inv. t. 80)

29. Amforă (fragment din toartă); $\mathrm{Lp}=5,6 \mathrm{~cm} ; \mathrm{dt}=$ $3.1 \mathrm{~cm}$. Pastã fină $(7.5 Y R$ 7,5/6). Toartă circulară în secţiune. (nr. inv. t. 81)

\section{Fructiere}

30. Fructieră (fragmentară); dg $=35 \mathrm{~cm}$. Pastă de culoare cărămizie (5YR 7/6), cu particule de nisip şi pietricele; ardere oxidantă; modelat cu mâna. Buza arcuitã orizontal. (nr. inv. t. 25)

31. Fructieră (fragmentară); $d g=28 \mathrm{~cm}$. Pastă fină, de culoare cărămizie ( $10 \mathrm{YR} 7 / 4)$, cu particule de nisip şi mică; ardere oxidantă; prelucrat la roată. Buza arcuită orizontal, cu marginea dreaptă, gâtul scurt şi arcuit. (nr. inv. t. 26)

32. Fructieră (fragmentară); dg = $22 \mathrm{~cm}$. Pastă fină, de culoare cenuşie (Gley 2 7/10B), cu particule de nisip şi pietricele; ardere reducătoare; prelucrat la roată. Buza arcuită orizontal, marginea decorată cu o canelură fină, gâtul scurt şi delimitat de corpul tronconic printr-un prag. (nr. inv. t. 27)

33. Fructieră (fragmentară); dg $=19 \mathrm{~cm}$. Pastă de culoare gălbuie, neagră la interior (5YR 7/6), cu particule de nisip şi pietricele; ardere oxidantă neuniformă; modelat cu mâna. Buza arcuită orizontal cu marginea rotunjită, gâtul scurt, uşor arcuit şi despărţit de corpul tronconic printr-un prag. (nr. inv. t. 28)

34. Fructieră (fragmentară); dg $=17 \mathrm{~cm}$. Pastă semifină, de culoare cărămizie $(7,5 Y R \quad 6,5 / 6)$, cu particule de nisip şi pietricele; ardere oxidantă; prelucrat la roată. Buza orizontală, faţetată, cu marginile rotunjite. (nr. inv. t. 29)

35. Fructieră (fragmentară); dg $=16 \mathrm{~cm}$. Pastă de culoare cenuşiu-negricioasă (Gley2 3/5BG), compactă, fină, cu particule de nisip; ardere reducătoare; prelucrat la roată. Buza orizontală, faţetată, gâtul scurt, uşor arcuit şi despărţit de corpul tronconic printr-un prag. (nr. inv. t. 30)

36. Fructieră (fragmentară); $d g=16 \mathrm{~cm}$. Pastă de culoare gălbui-cenuşie, neagră la interior $(7,5 \mathrm{YR}$ 7/6), cu particule de nisip şi pietricele; ardere oxidantă neuniformă; prelucrat la roată. Buza arcuitã orizontal cu marginile drepte, despărţită de corpul vasului printr-un prag. (nr. inv. t. 31)

37. Fructieră (picior fragmentar) $\mathrm{db}=6 \mathrm{~cm} ; \mathrm{dp}=$ 7.5. Pastă grosieră, de culoare cărămizie (5YR 6/6), cu particule de nisip şi pietricele; ardere oxidantă; modelat cu mâna. Piciorul scurt, de formă cilindrică. (nr. inv. t. 32)

38. Fructieră (picior fragmentar); $d p=6,5 \mathrm{~cm}$. Pastă fină, de culoare cenuşie (Gleyl 6/10Y), cu particule de nisip; ardere reducătoare; prelucrat la roată. Piciorul de formă cilindrică, decorat cu o canelură. (nr. inv. t. 33)

\section{Oale borcan / vase "pântecoase"}

39. Oală borcan (fragmentară); dg = $33 \mathrm{~cm}$. Pastă grosieră, de culoare cărămizie (7,5YR 6/4), cu particule de nisip şi pietricele; ardere oxidantă; modelat cu mâna. Buza rotunjtă. (nr. inv. t. 34)

40. Oală borcan (fragmentară); dg $=32 \mathrm{~cm}$. Pastă de culoare cărămizie $(2,5 Y R 7 / 6)$, cu particule de nisip şi pietricele; ardere oxidantă; modelat cu mâna. Buza uşor arcuită, cu marginea rotunjită. (nr. inv. t. 35)

41. Oală borcan (fragmentară); dg $=28 \mathrm{~cm}$. Pastă grosieră, de culoare cărămizie (5YR 7/6), cu particule de nisip şi pietricele; ardere oxidantă; modelat cu mâna. Buza verticală, cu marginea ratunjită. (nr. inv. t. 36)

42. Vas "pântecos" (fragmentar); $d g=22 \mathrm{~cm}$. Pastă grosieră, de culoare cărămizie (5YR 7/6), cu particule de nisip şi pietricele; ardere oxidantă; modelat cu mâna. Buza răsfrântă oblic. (nr. inv. t. 37)

43. Oală borcan (fragmentară); $d g=22 \mathrm{~cm}$. Pastă de culoare cărămizie $(5 Y R \quad 6 / 6)$, cu particule de nisip şi pietricele; ardere oxidantă; modelat cu mâna. Buza uşor arcuită, cu marginea rotunjită. (nr. inv. t. 38)

44. Vas „pântecos” (fragmentar); $\mathrm{dg}=21 \mathrm{~cm}$. Pastă de culoare cărămizie $(2,5 Y R \quad 7 / 6)$, cu particule de nisip şi pietricele; ardere oxidantă neuniformă; modelat cu mâna. Buza răsfrântă oblic în exterior, rotunjită. (nr. inv. t. 39)

45. Oală borcan (fragmentară); $d g=18 \mathrm{~cm}$. Pastă de culoare cărămizie (5YR 7/8), cu particule de nisip şi pietricele; ardere oxidantă; modelat cu mâna. Buza verticală cu marginea teşită oblic, decorat cu brâul dispus vertical. (nr. inv. t. 40)

46. Oală borcan (fragmentar); $\mathrm{dg}=15 \mathrm{~cm}$. Pastă de culoare cărămizie (5YR 7/6), cu particule de nisip, pietricele şi resturi vegetale; ardere oxidantă; modelat cu mâna. Buza răsfrântă, cu marginea rotunjită. (nr. inv. t. 41)

47. Oală borcan ? (fragmentară); $d g=15 \mathrm{~cm}$. Pastă de culoare cărămizie (10R 5/6), cu particule de nisip şi pietricele; ardere oxidantă; modelat cu mâna. Buza uşor răsfrântă, marginea rotunjită. (nr. inv. t. 42) 
48. Oală borcan (fragmentară); db=17 cm. Pastă de culoare cărămizie $(2,5 Y R \quad 6 / 6)$, cu particule de nisip, pietricele și resturi vegetale; ardere oxidantă; modelat cu mâna. Baza dreaptă. (nr. inv. t. 43)

49. Oală borcan (fragmentară); db=15 cm. Pastă de culoare cărămizie (5YR 7/6), cu particule de nisip, pietricele şi resturi vegetale; ardere oxidantă; modelat cu mâna. Baza dreaptã. (nr. inv. t. 44)

50. Oală borcan (fragmentară); db=11 cm. Pastă grosieră, de culoare cărămizie $(10 \mathrm{R} \quad 6 / 8)$, cu particule de nisip şi pietricele; ardere oxidantă; modelat cu mâna. Baza dreaptă. (nr. inv. t. 45)

51. Oală borcan (fragmentară); db=9 cm. Pastă grosieră de culoare cărămizie $(7,5 \mathrm{YR} \quad 7 / 4)$, cu particule de nisip şi pietricele; ardere oxidantă neuniformă; modelat cu mâna. Baza dreaptă. (nr. inv. t. 46)

52. Oală borcan (fragmentară). Pastă grosieră, de culoare cărămizie (5YR 7/6), cu particule de nisip, pietricele şi resturi vegetale; ardere oxidantă; modelat cu mâna. Fragment ceramic păstrând unul din butonii-apucătoare, de formă cilindrică. (nr. inv. t. 47)

53. Oală borcan (fragmentară). Pastă de culoare cărămizie $(7,5 Y R \quad 7 / 6)$ cu particule de nisip, pietricele şi resturi vegetale; ardere oxidantă; modelat cu mâna. Fragment ceramic decorat cu brâu alveolar. (nr. inv. t. 48)

54. Oală borcan (fragmentară). Pastă de culoare gălbuie $(2,5$ YR 6/8), cu particule de nisip şi pietricele; ardere oxidantå; modelat cu mâna. Fragment ceramic păstrând unul din butonii de formă ovoidală, legat de ceilalţi butoni ai vasului de un brâu alveolar. (nr. inv. t. 49)

55. Oală borcan (fragmentar). Pasta de culoare cărămizie (5YR 7/6), cu particule de nisip şi pietricele; ardere oxidantă; modelat cu mâna. Fragment ceramic decorat cu brâu alveolar. (nr. inv. t. 50)

56. Oală borcan (fragmentar). Pastă de culoare cărămizie $(2,5 Y R$ 5/8), cu particule de nisip şi pietricele; ardere oxidantă; modelat cu mâna. Fragment ceramic păstrând unul din butonii de formă cilindrică, vasul fiind decorat probabil cu impresiuni digitale. (nr. inv. t. 51)

57. Oală borcan (fragmentară). Pastă de culoare cărămizie $(2,5 Y R$ 6/8), cu particule de nisip şi pietricele; ardere oxidantă; modelat cu mâna. Fragment ceramic păstrând unul din butonii de formă ovoidală, arcuit. (nr. inv. t. 52)

58. Oală borcan (fragmentară). Pastă de culoare cărămizie (5YR7/6), cu particule de nisip şi pietricele; ardere oxidantă; modelat cu mâna. Fragment ceramic păstrând unul din butonii de formă cilindrică şi resturile brâului alveolar care unea butonii apucătoare. (nr. inv. t. 53)

59. Oală borcan (fragmentară). Pastă de culoare cărămizie (5YR 7/8) cu particule de nisip şi pietricele; ardere oxidantă; modelat cu mâna. Fragment ceramic decorat cu brâu alveolar în ghirlandă. (nr. inv. t. 54)

60. Oală borcan (fragmentară). Pastă de culoare cărămizie (5YR 7/8), cu particule de nisip și pietricele; ardere oxidantă; modelat cu mâna. Fragment ceramic decorat cu brâu alveolar în ghirlandà. (nr. inv. t. 55)

61. Oală borcan (fragmentară). Pastă grosieră, de culoare cărămizie (5YR 7/4), cu particule de nisip, pietricele şi resturi vegetale; ardere oxidantă; modelat cu mâna. Fragment ceramic păstrând unul din butonii de formă cilindrică uşor alveolaţi şi brâu cu alveole dispus în ghirlandă. (nr. inv. t. 56)

62. Oală borcan (fragmentară). Pastă grosieră, de culoare cărămizie (7,5YR 7/6), cu particule de nisip, pietricele şi resturi vegetale; ardere oxidantă neuniformă; modelat cu mâna. Fragment ceramic păstrând unul din butonii de formă cilindrică uşor alveolaţi şi brâu cu alveole dispus în ghirlandă. (nr. inv. t. 57)

63. Oală borcan (fragmentară). Pastă grosieră, de culoare cărămizie (10YR 7/4), cu particule de nisip, pietricele, resturi vegetale; ardere oxidantă neuniformă; modelat cu mâna. Fragmentul ceramic păstreză unul dintre butoni, uşor alveolaţi şi o parte din brâu cu alveole dispus în ghirlandă. (nr. inv. t. 58)

64. Oală borcan (fragmentară). Pastă de culoare cărămizie $(7,5 \mathrm{YR} 7 / 4)$, cu particule de nisip și pietricele; ardere oxidantă; modelat cu mâna. Fragment ceramic păstrând unul din butonii de formă conică legaţi printr-un brâu cu alveole. (nr. inv. t. 59)

65. Oală borcan (fragmentară). Pastă grosieră, de culoare cărămizie (7,5YR 7/3), cu particule de nisip şi pietricele; ardere oxidantă neuniformă; modelat cu mâna. Fragment ceramic decorat cu incizii verticale. (nr. inv. t. 60)

\section{Căni / cupe}

66. Cană (fragmentară); $d g=12 \mathrm{~cm}$. Pastă de culoare cărămizie $(2,5 Y R$ 7/8), cu particule de nisip şi pietricele; ardere oxidantă; modelat cu mâna. Buza vasului dreaptă cu marginea rotunjită, păstrând urmele de prindere a torţii, decorat cu brâu dispus vertical. (nr. inv. t. 61) 
67. Cană (fragmentară); $d g=10 \mathrm{~cm}, d m=12 \mathrm{~cm}$. Pastă fină, de culoare cenuşie (Gleyl 7/10Y), cu particule de nisip şi mică; ardere reducătoare; prelucrată la roată. Buza înclinată spre exterior, rotunjită, corp cu formă tronconică, toarta supraînălţată, canelată. (nr. inv. t. 62)

68. Cană (fragmentară). Pastă grosieră, de culoare brun-cenuşie $(2.5 Y$ 6/2), cu particule de nisip şi pietricele; ardere reducătoare; modelat cu mâna. Fragment ceramic păstrând resturile torţii, corpul de formã tronconică. (nr. inv. t. 63)

69. Cupă (fragmentară); dg $=12 \mathrm{~cm}$. Pastă de culoare cărămizie $(2,5 Y R 7 / 8)$, cu particule de nisip şi mică; ardere oxidantă neuniformă. Buza dreaptă, rotunjită la exterior. (nr. inv. t. 64)

\section{Castroane / boluri}

70. Castron (fragmentar); dg $=33 \mathrm{~cm}$. Pastă grosieră, de culoare cenuşiu-negriciosă (5YR 7/2), cu particule de nisip și pietricele; ardere reducătoare; prelucrat la roată. Buza arcuită orizontal cu marginea rotunjită, urme de ardere secundară. (nr. inv. t. 65)

71. Castron (fragmentar); $d g=25 \mathrm{~cm}$. Pastă fină, de culoare cărămizie $(7,5 \mathrm{YR}$ 8/4), cu particule de nisip; ardere oxidantă; prelucrat la roată. Buza arcuită orizontal. (nr. inv. t. 66)

72. Castron (fragmentar); $d g=23 \mathrm{~cm}$. Pastă fină, de culoare cenuşie (Gleyl 7/Y), cu particule de nisip; ardere reducătoare; prelucrat la roată. Buza fătuită, despărţită de corp printr-un prag. (nr. inv. t. 67)

73. Castron (fragmentar); $d g=23 \mathrm{~cm}$. Pastă fină, de culoare cenuşie $(2,5 Y 7 / 2)$, cu particule de nisip, mică şi pietricele; ardere reducătoare; prelucrat la roată. Buza orizontală, cu marginea rotunjită, decorată cu o canelură greu sesizabilă, gâtul scurt, arcuit, despărţit de corp printr-un prag. (nr. inv. t. 68)

74. Castron (fragmentar); $d g=23 \mathrm{~cm}$. Pastă fină, de culoare cenuşie (Gleyl 7/10Y), cu particule de nisip; ardere reducătoare; prelucrat la roată. Buza arcuită, gâtul scurt, uşor arcuit şi despărţit de corp printr-un prag. (nr. inv. t. 69)

75. Castron (fragmentar); dg $=23 \mathrm{~cm}$. Pastă grosieră, de culoare cărămizie $(10 \mathrm{R} \quad 6 / 8)$, cu particule de nisip şi pietricele, arderea oxidantă neuniformă, modelat cu mâna. Buză dreaptă, cu marginea rotunjită. (nr. inv. t. 70)

76. Castron (fragmentar); dg $=22 \mathrm{~cm}$. Pastă de culoare cenuşiu-gălbui $(2,5 \mathrm{Y} 7 / 4)$, cu particule de nisip; ardere reducătoare incompletă; modelat cu mâna. Buza arcuită, răsfrântă, rotunjită. (nr. inv. t. 71)
77. Castron (fragmentar); $d g=18 \mathrm{~cm}$. Pastă fină, de culoare cenuşie (Gley $17 / 10 y$ ), cu particule de nisip; ardere reducătoare; prelucrat la roată. Buza rotunjită, uşor evazată, decorată cu o incizie meandrică imediat sub aceasta. (nr. inv. t. 72)

78. Castron (fragmentar, se păstrează un fragment din partea superioară); $d g=15 \mathrm{~cm}$. Pastă fină, de culoare cenuşie (Gleyl 7/10Y), cu particule de nisip; ardere reducătoare; prelucrat la roată. Buza dreaptă, faţetată, cu marginea rotunjită, gâtul scurt, arcuit. (nr. inv. t. 73)

79. Bol (fragmentar, se păstrează un fragment din buză); $d g=14 \mathrm{~cm}$. Pastă de culoare cenuşie (Gley 2 7/5B), cu particule de nisip şi pietricele; ardere reducătoare; prelucrat la roată. Buza orizontală, fațetată, corp globular. (nr. inv. t. 74)

\section{Ulcioare}

80. Ulcior (fragmentar); dg $=10 \mathrm{~cm}$. Pastă fină, de culoare cenuşie (Gley 1 6/10Y), cu particule de nisip şi mică; ardere reducătoare; prelucrat la roată. Buza răsfrântă, arcuită spre exterior. (nr. inv. t. 75)

81. Ulcior (fragmentar); dg $=8 \mathrm{~cm}$. Pastã de culoare cărămizie (5YR 7/8), cu particule de nisip; ardere oxidantă; prelucrat la roată. Buza dreaptă, rotunjită la exterior. (nr. inv. t. 76)

82. Ulcior (fragmentar); $d g=7 \mathrm{~cm}$. Pastă fină, de culoare cenuşie (Gley 7,5YR 5/1), cu particule de nisip; ardere reducătoare; prelucrat la roată. Buza arcuită, răsfrântă, cu marginea rotunjită. (nr. inv. t. 77)

\section{Strecurători}

83. Vas strecurătoare (fragmentar); $\mathrm{dm}=12 \mathrm{~cm}$. Pastă fină, de culoare cenuşie (Gley 1 7/10Y), cu particule de nisip; ardere reducătoare; prelucrat la roată. Partea superioară a vasului nu se mai păstrează, corpul semisferic, cu pereţii şi baza perforate. Decor alcătuit din linii incizate în zigzag, sub acestea aflându-se un al doilea registru format din patru linii drepte incizate încadrând o linie incizată meandrică. (nr. inv. t. 78)

84. Vas strecurătoare (fragmentar); $d g=15 \mathrm{~cm}$. Pasta fină, de culoare cenuşie (Gley 1 7/10Y), cu particule de nisip; ardere reducătoare; prelucrat la roată. Buza răsfrântă, marginea fiind dreaptă, gât scurt, umăr profilat. (nr. inv. t. 79)

\section{GROAPA NR. 3 (Cpl. 3) (planşa 27)}

\section{Oale borcan}

85. Oală borcan (fragmentară); dg $=28 \mathrm{~cm}$. Pastă de culoare cărămizie $(2,5 \mathrm{YR} 6 / 8)$, cu particule de nisip, pietricele, resturi vegetale; arderea oxidantă, 
neuniformă; modelat cu mâna. Buza verticală cu marginea rotunjită, corp cu pereţii drepţi, uşor înclinaţi spre interior; decorat cu linii incizate dispuse vertical sau oblic la nivelul butonilor apucătoare de formă cilindrică. (nr. inv. t. 82)

86. Oală borcan (fragmentară); $\mathrm{dg}=21 \mathrm{~cm}$. Pastăa de culoare cărămizie $(2,5$ YR 6/8). Vas cu pereţi drepți, buza verticală cu marginea dreaptă, decorat cu brâu alveolar aplicat în ghirlandă şi unind butonii apucătoare de formă cilindrică; deasupra acestui brâu vasul prezintă impresiuni digitate dispuse neuniform. (nr. inv. t. 83)

87. Oală borcan (fragmentară); $d g=20 \mathrm{~cm}$. Pastă de culoare cărămizie (7,5YR 6/6), cu particule de nisip, pietricele, resturi vegetale; ardere oxidantă, neuniformă. Vas cu pereţi drepţi, buza verticală cu marginea rotunjită, uşor înclinată spre interior, decorat cu linii incizate dispuse oblic la nivelul butonilor apucatoare de formă cilindrică și impresiune transversală (?).(nr. inv. t. 84)

88. Oală borcan (fragmentară); db =12. Pastă de culoare cărămizie (5YR 7/8), cu particule de nisip, pietricele, resturi vegetale; ardere oxidantă; modelat cu mâna. Baza dreaptă. (nr. inv. t. 85)

\section{Cană}

89. Cană (?) (fragmentar, se păstrează un fragment din bază); db $=7 \mathrm{~cm}$. Pastă de culoare cărămizie (5YR 7/6), cu particule de nisip şi pietricele; ardere oxidantă; modelat cu mâna. Baza dreaptă, rotunjită, uşor pronunţată la exterior. (nr. inv. t. 86)

\section{SONDAJE ŞI SECTIUNI (planșele 28-29)}

90. Fructieră (fragmentară, se păstrează un fragment din partea superioară); S II; dg $=26 \mathrm{~cm}$. Pastă de culoare cărămizie (5YR 7/6); modelat cu mâna. Buza vasului orizontală, cu marginea rotunjită. (nr. inv. t. 91)

91. Fructieră (fragmentar, se păstrează un fragment din partea superioară, buză); S II; dg $=24 \mathrm{~cm}$., Pastă fină, de culoare cărămizie (Gley l 6/10Y), cu nisip şi pietricele; arderea oxidantă; lucrată la roată. Buză arcuită orizontal. (nr. inv. t. 87)

92. Fructieră (fragmentară, se păstrează un fragment din buză); $S 035 ; d g=21 \mathrm{~cm}$. Pastă fină, de culoare cenuşie (Gleyl 4/N), cu nisip și pietricele; prelucrat la roată. Buza arcuită orizontal, despărţită de corp printr-un prag. (nr. inv. t. 95)

93. Vas "pântecos" (fragmentar, se păstrează un fragment din partea superioară); S II; dg $=18 \mathrm{~cm}$. Pastã de culoare cărămizie (10R 6/6), cu nisip și pietricele; ardere oxidantă. Fragment din buza uşor răsfrântă oblic spre exterior, pereţii acestui vas fiind arcuiţi. (nr. inv. t. 90)

94. Cană (fragmentară, se păstrează toarta); S IV; $\mathrm{dg}=7 \mathrm{~cm}$. Pastă grosieră, de culoare cărămizie (5YR 6/8), cu nisip şi pietricele; modelat cu mâna. Toartă de formă inelară, ovală în secţiune. (nr. inv. t. 93)

95. Strachină (?) (fragmentară, se păstrează un fragment din corpul vasului); S 4. Pastã semifină, de culoare crem $(5,5$ YR 8/6), cu nisip, pietricele. Vasul de formă tronconică, decorat cu linii incizate care încadrează posibile incizii meandrice (solzi ?). (nr. inv. t. 92)

96. Vas borcan (fragmentar, se păstrează unul din butoni); S I. Pastă grosieră, de culoare cărămizie (5YR 5/8), neagră la interior; ardere reducătoare; modelat cu mâna. Buton de formă cilindrică. (nr. inv. t. 88)

97. Vas borcan (fragmentar, se păstrează un fragment din bază); S I; db $=11 \mathrm{~cm}$. Pastă de culoare cărămiziu-roşiatică (5YR 6/6); ardere reducătoare; modelat cu mâna. Baza dreaptă. (nr. inv. t. 89)

98. Oală (fragmentară, se păstrează un fragment din partea superioară); $S 035 ; d g=21 \mathrm{~cm}$. Pastă fină, de culoare cărămizie $(2,5 Y R \quad 6 / 8)$; ardere oxidantă; prelucrat la roată. Vas decorat cu o incizie vălurită imediat sub buză (dreaptă, puternic profilată) şi o incizie liniară în registrul secund. (nr. inv. t. 96)

99. Vas borcan (se păstrează un fragment din corpul vasului); $\mathrm{S} \mathrm{VI} ; \mathrm{dg}=20 \mathrm{~cm}$. Pastă grosieră, de culoare cărămizie (2,5 YR 6/8); ardere oxidantă; modelat cu mâna. Fragment ceramic cu brâu alveolar. (nr. inv. t. 94)

\section{Studiu arheozoologic ${ }^{27}$}

Fauna descoperită cu prilejul cercetărilor preventive din situl de la Baloteşti - punct Flower City este redusă numeric, conţinând doar 15 resturi ce provin din două contexte arheologice diferite (complexul 2 şi contextul 4), care însă sunt datate în aceeaşi perioadă, respectiv Latène. Speciile identificate aparţin numai mamiferelor, fiind vorba atât de cele domestice: Bos taurus (vită domestică), Ovis aries/Capra hircus (ovicaprine), Sus

\footnotetext{
27 Studiul arheozoologic a fost realizat de către colegul nostru, dr. Adrian Bălăşescu, căruia autorii îi mulţumesc şi pe această cale.
} 
domesticus (porc), cât şi cele sălbatice: Cervus elpahus (cerb).

Fauna prezintă toate caracteristicile unor resturi menajere: o puternică fragmentare şi urme de dinţi, de carnivore în special (posibil şi de suine domestice). Starea de conservare a materialului este extrem de proastă, numeroase fragmente faunistice sunt corodate şi fisurate longitudinal, ceea ce a împiedicat observarea diferitelor urme de intervenţie umană (mai ales descărnarea). Fisurarea longitudinală a oaselor ilustrează faptul că fauna a fost supusă unor procese tafonomice extrem de complexe, cum ar fi variaţiile de temperatură, de umiditate etc. $^{28}$

În aceste condiţii, vârstele de abataj (de sacrificare) au fost estimate având ca referinţă lui E. Schmid ${ }^{29}$.

Repartiţia resturilor faunistice pe contexte arheologice, specii şi elemente anatomice poate fi observată în tabelul nr. 1.

În cadrul Cpx 2 (la o adâncime de 0,55 m) au fost identificat 5 resturi de vacă provenind de la un individ subadult/adult, 3 fragmente de la un ovicaprin subadult/adult şi un rest de cerb de la un animal de peste 2,5 ani (pe baza unui radius epifizat distal). Acestora li se adaugă şi un rest diafizar de mamifer de talie mare.

În contextul 4 au fost descoperite 3 resturi de vită, provenind de la un individ de circa $2^{3 / 4}-3$ ani (prezintă P4 în curs de ieşire), un incisiv 1 superior de porc neuzat, provenind de la un individ de circa 12-14 luni şi un fragment de ovicaprin subadult/adult.

Măsurătorile resturilor faunistice au fost realizate cu un şubler care prezintă o precizie instrumentală de $1 / 10$ milimetri. Acestea au fost luate după recomandările lui von den Driesch $^{30}$.

Fragmentarea accentuată a resturilor faunistice nu a permis prelevarea unui număr foarte mare de măsurători care să ne permită caracterizarea din punct de vedere dimensional a diferitelor specii, totuşi acestea se încadrează

\footnotetext{
28 Lyman 1994.

${ }^{29}$ Schmid 1972

${ }^{30}$ von den Driesch 1976.
}

în valorile cunoscute pentru perioada studiată (vezi Anexa 1 -Biometrie).

Din păcate cantitatea de faună determinată este extrem de redusă numeric şi nu permite formularea unor observaţii asupra paleoeconomiei de origine animală a aşezării (?) de la Baloteşti - Flower City, dar cert este faptul că aceasta se bazează în principal pe activitatea de creştere a animalelor domestice. 
Tabel nr. 1 - Repartiţia numerică a resturilor faunistice pe contexte arheologice, specii de mamifere şi elemente anatomice

\begin{tabular}{|c|c|c|c|c|c|c|}
\hline \multirow[b]{2}{*}{ 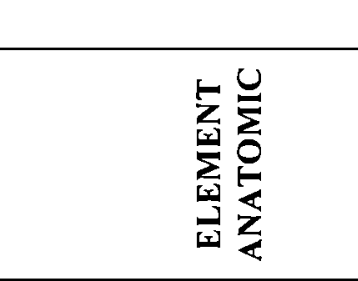 } & \multicolumn{3}{|c|}{ Cpl. 2} & \multicolumn{3}{|c|}{ Context 4} \\
\hline & 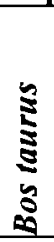 & 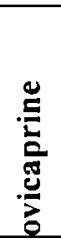 & 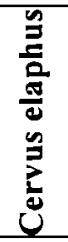 & 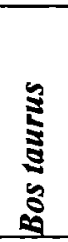 & 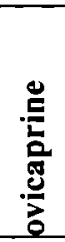 & 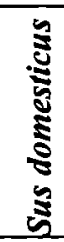 \\
\hline Dentes sup. & & & & & & 1 \\
\hline Mandibula & & & & 1 & & \\
\hline Dentes inf. & 1 & & & & & \\
\hline Costae & & 1 & & & & \\
\hline Humerus & 1 & & & 1 & & \\
\hline Radius & 2 & & 1 & & 1 & \\
\hline Metacarpus & & & & 1 & & \\
\hline Pelvis & 1 & & & & & \\
\hline Tibia & & 1 & & & & \\
\hline Metapodalia & & 1 & & & & \\
\hline TOTAL determinate & 5 & 3 & 1 & 3 & 1 & 1 \\
\hline TOTAL indeterminate & & 1 & & & & \\
\hline
\end{tabular}

Anexa 1 - Biometrie (măsurătorile sunt efectuate după von den Driesch, 1976 şi sunt exprimate în milimetri)

Bos taurus

\begin{tabular}{|l|r|}
\hline Radius & 2 \\
\hline$D p$ & 33.3 \\
\hline
\end{tabular}

\begin{tabular}{|l|r|}
\hline Metacarp & 10 \\
\hline $\mathrm{Bp}$ & 56.5 \\
\hline $\mathrm{Dp}$ & 33.4 \\
\hline
\end{tabular}

\section{Cervus elaphus}

\begin{tabular}{|l|r|}
\hline Radius & 9 \\
\hline $\mathrm{Bp}$ & 53.6 \\
\hline $\mathrm{BFp}$ & 49.3 \\
\hline $\mathrm{DP}$ & 37.4 \\
\hline
\end{tabular}

\section{BIBLIOGRAFIE}

Coteț 1973 - P. V. Coteț, Geomorfologia României, Bucureşti, 1973.

Cotet 1976 - P.V. Coteț, Câmpia Română. Studiu de geomorfologie integrată, Bucureşti, 1976.

Crişan 1969 - I. H. Crişan, Ceramica daco-getică cu specială privire la Transilvania, Bucureşti, 1969.

Damian et alii 2009 - P. Damian, O. Tentea, C. Borş, S. Cleşiu, M. Florea, Al. Raţiu, Baloteşti (raport preliminar 2008), CCA 2009, nr. 118, p. 258-259 (disponibil on-line la adresa http://www.cimec.ro/Arheologie/cronicaCA2009/cd/index.htm) [accesat 20.10.2010]

von den Driesch 1976 - A. von den Driesch, $A$ guide to the measurement of animal bones from archaeological sites, Peabody Museum Bulletin 1, Harvard, 1976.

Grant et alii 2005 - J. Grant, S. Gorin, N. Fleming, The archaeology coursebook: an introduction to study skills, topics and methods, Routledge, 2005.

Green 2002 - K. Greene, Archaeology: an introduction, Routledge, 2002.

Johnson 2005 - M. Johnson, Thinking about landscape, în C. Renfrew, P. Bahn (eds.), Archaeology. The Key Concepts, London-New York, 2005, p. 156-159.

Legea nr. 2001-44/2001 -_L Loi $\mathrm{n}^{\circ}$ 2001-44 du 17 janvier 2001 relative à l'archéologie préventive, version consolidće au 24 février 2004, http://www. legifrance.gouv.fr [accesat 20.10.2010]

Lyman 1994 - R. L. Lyman, Vertebrate Taphonomy, Cambridge Manuals in Archaeology, Cambridge, 1994.

Mihăilescu 1969 - V. Mihăilescu, Geografia fizică a României, Bucureşti, 1969.

Neumann, Sanford 2001 - Th. W. Neumann, R. M. Sanford, Practicing Archaeology. A Training Manual for Cultural Resources Archaeology, Walnut Creek, California, 2001. 
PPG $16-$ *** $^{* *}$ Planning Policy Guidance 16: Archaeology and planning, 1990, http://www.communities.gov.uk/documents/planningandbuilding/pdf/156777 [accesat 20.10.2010]

PPS $5-{ }^{* * *}$, Planning Policy Statement 5: Planning for the Historic Environment, 2010, http://www.communities.gov.uk/publications/planningandbuilding/pps5 [accesat 20.10.2010]

Roskams 2001 - S. Roskams, Excavation, Cambridge, 2001.

Roşu 1980 - Al. Roşu, Geografia fizică a României, Bucureşti, 1980.

Sandu 1992 - V. Sandu, Cercetări arheologice de suprafată din nordul Sectorului Agricol llfov, CAB, IV, 1992 , p. $289-323$.

Schmid 1972 - E. Schmid, Atlas of Animal Bones, Amsterdam-London-New York, 1972.

Şerbănescu, Trohani 1978 - D. Şerbănescu, G. Trohani, Cercetări arheologice pe Valea Mostiştei, File de Istorie. 1978, p. 17-42.

Trohani 1997 - G. Trohani, Assezarea de la Popeşti, jud. Giurgiu. Campaniile 1988-1991 Secfiunea P. Raport preliminar, CercA, X, p. 193-229.

Trohani 1988 - G. Trohani, Noi cercetări arheologice de suprafată pe Valea Moștistei, CCDJ, II, 1998, p. 15 33.

Trohani 2000 - G. Trohani, Obiecte din lut ars şi piatra, precum şi vase ceramice descoperite in aşezarea getică de la Vadu Anii, comuna Bräneşti (jud. Ilfov), CercA, XI, 2000, p. 371-401.

Ujvári 1972 - I. Ujvári, Geografia apelor României, Bucureşti, 1972.

\section{LISTA ILUSTRATIEI}

Planșa 1 - Localizarea generală a sitului arheologic Balotești - Flower City (jud. Ilfov)

Planşa 2 - Vedere generală asupra sitului arheologic Baloteşti - Flower City

Planşa 3 - Hartă privind distribuţia potenţialului arheologic de-a lungul principalelor văi din nordul judeţului Ilfov (apud Sandu 1992)

Planşa 4-Model digital al terenului în zona sitului arheologic Baloteşti - Flower City

Planşa 5 - Evoluţia dezvoltării imobiliare (2002-2006) în zona sitului arheologic Baloteşti - Flower City

Planşa 6 - Plan de situaţie a sitului de la Baloteşti - Flower City

Planşa 7 - Detalierea planului de situaţie a sitului arheologic Baloteşti - Flower City

Planşa 8 - Imagini din timpul cercetărilor arheologice în cadrul sitului arheologic Balotești - Flower City

Planşa 9 - Imagini din timpul cercetării complexelor arheologice

Planşa 10 - Plan şi profil al gropii nr. 1 (Cpl. 1)

Planşa 11 - Plan şi profil al gropii nr. 2 (Cpl. 2)

Planşa 12 - Materialul arheologic descoperit în groapa nr. 1 (Cpl. 1) (nr. cat. 1-5)

Planşa 13 - Materialul arheologic descoperit în groapa nr. 1 (Cpl. 1) (nr. cat. 6-10)

Planşa 14 - Materialul arheologic descoperit în groapa nr. 1 (Cpl. 1) (nr. cat. 11-14)

Planșa 15 - Materialul arheologic descoperit în groapa nr. 1 (Cpl. 1) (nr. cat. 15-20)

Planşa 16 - Materialul arheologic descoperit în groapa nr. 1 (Cpl. 1) (nr. cat. 21-24)

Planşa 17 - Materialul arheologic descoperit în groapa nr. 2 (Cpl. 2) (nr. cat. 25-29)

Planşa 18 - Materialul arheologic descoperit în groapa nr. 2 (Cpl. 2) (nr. cat. 30-33)

Planşa 19 - Materialul arheologic descoperit în groapa nr. 2 (Cpl. 2) (nr. cat. 34-38)

Planşa 20 - Materialul arheologic descoperit în groapa nr. 2 (Cpl. 2) (nr. cat. 39-44)

Planşa 21 - Materialul arheologic descoperit în groapa nr. 2 (Cpl. 2) (nr. cat. 45-51)

Planşa 22 - Materialul arheologic descoperit în groapa nr. 2 (Cpl. 2) (nr. cat. 52-59)

Planşa 23 - Materialul arheologic descoperit în groapa nr. 2 (Cpl. 2) (nr. cat. 60-69)

Planşa 24 - Materialul arheologic descoperit în groapa nr. 2 (Cpl. 2) (nr. cat. 70-73)

Planşa 25 - Materialul arheologic descoperit în groapa nr. 2 (Cpl. 2) (nr. cat. 74-78)

Planşa 26 - Materialul arheologic descoperit în groapa nr. 2 (Cpl. 2) (nr. cat. 79-84)

Planşa 27 - Materialul arheologic descoperit în groapa nr. 3 (Cpl. 3) (nr. cat. 85-89)

Planşa 28 - Materialul arheologic descoperit în sondaje şi seç̧iuni (nr. cat. 90-93)

Planşa 29 - Materialul arheologic descoperit în sondaje şi secţiuni (nr. cat. 94-97)

\section{LIST OF ILLUSTRATIONS}

Plate 1 - General location of the archaeological site Baloteşti - Flower City (Ilfov county)

Plate 2 - General view of the archaeological site Baloteşti - Flower City

Plate 3 - Distribution map of the archaeological evidences along the main valleys from the north part of Ilfov county (apud Sandu 1992)

Plate 4 - Digital model of the terrain on the area of the archaeological site Baloteşti - Flower City 
Plate 5 - Evolution of the residential development (2002-2006) on the area of the archaeological site Baloteşti - Flower City

Plate 6 - General plan of the archaeological site Baloteşti - Flower City

Plate 7 - Detailed plan of the on the area of the archaeological site Baloteşti-Flower City

Plate 8 - Images during the archaeological excavations on the site Baloteşti - Flower City

Plate 9 - Images during the research of the archaeological complexes

Plate 10 - Plan and cross-section of pit no. 1 (Cpl. 1)

Plate 11 - Plan and cross-section of pit no. 2 (Cpl. 2)

Plate 12 - Archaeological material uncovered in pit no. 1 (Cpl. 1) (cat. nos. 1-5)

Plate 13 - Archaeological material uncovered in pit no. 1 (Cpl. 1) (cat. nos. 6-10)

Plate 14 - Archaeological material uncovered in pit no. 1 (Cpl. 1) (cat. nos. 11-14)

Plate 15 - Archaeological material uncovered in pit no. 1 (Cpl. 1) (cat. nos. 15-20)

Plate 16 - Archaeological material uncovered in pit no. 1 (Cpl. 1) (cat. nos. 21-24)

Plate 17 - Archaeological material uncovered in pit no. 2 (Cpl. 2) (cat. nos. 25-29)

Plate 18 - Archaeological material uncovered in pit no. 2 (Cpl. 2) (cat. nos. 30-33)

Plate 19 - Archaeological material uncovered in pit no. 2 (Cpl. 2) (cat. nos. 34-38)

Plate 20 - Archaeological material uncovered in pit no. 2 (Cpl. 2) (cat. nos. 39-44)

Plate 21 - Archaeological material uncovered in pit no. 2 (Cpl. 2) (cat. nos. 45-51)

Plate 22 - Archaeological material uncovered in pit no. 2 (Cpl. 2) (cat. nos. 52-59)

Plate 23 - Archaeological material uncovered in pit no. 2 (Cpl. 2) (cat. nos. 60-69)

Plate 24 - Archaeological material uncovered in pit no. 2 (Cpl. 2) (cat. nos. 70-73)

Plate 25 - Archaeological material uncovered in pit no. 2 (Cpl. 2) (cat. nos. 74-78)

Plate 26 - Archaeological material uncovered in pit no. 2 (Cpl. 2) (cat. nos. 79-84)

Plate 27 - Archaeological material uncovered in pit no. 3 (Cpl. 3) (cat. nos. 85-89)

Plate 28 - Archaeological material uncovered in trial trenches and archaeological sections (cat. nos. 90-93)

Plate 29 - Archaeological material uncovered in trial trenches and archaeological sections (cat. nos. 94-97)

\section{TRADUCEREA REZUMATULUI:}

\section{Corina Borş}

\section{DESEN:}

Georgiana Ducman

OVIDIU TENTEA SORIN CLEŞIU

MIHAI FLOREA

CORINA BORŞ

ALEXANDRU RATIU

Muzeul Naţional de Istorie a României

Calea Victoriei, nr. 12, sector 3, 030026

București

ovidiu_tentea@yahoo.com clesiusorin@gmail.com mihaimfs@yahoo.com corina.bors73@gmail.com sandu_ratiu@yahoo.com 

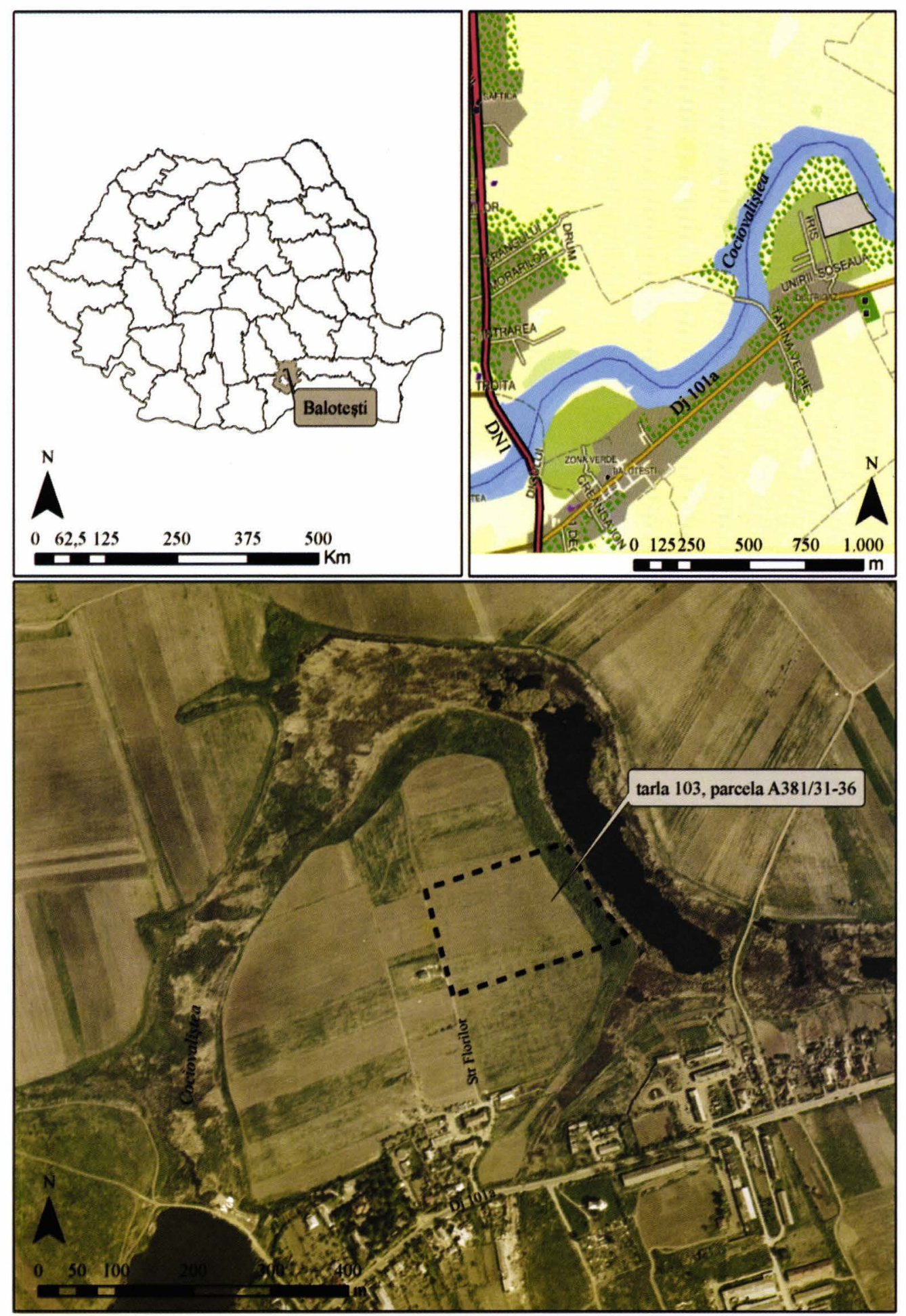

PI. 1 


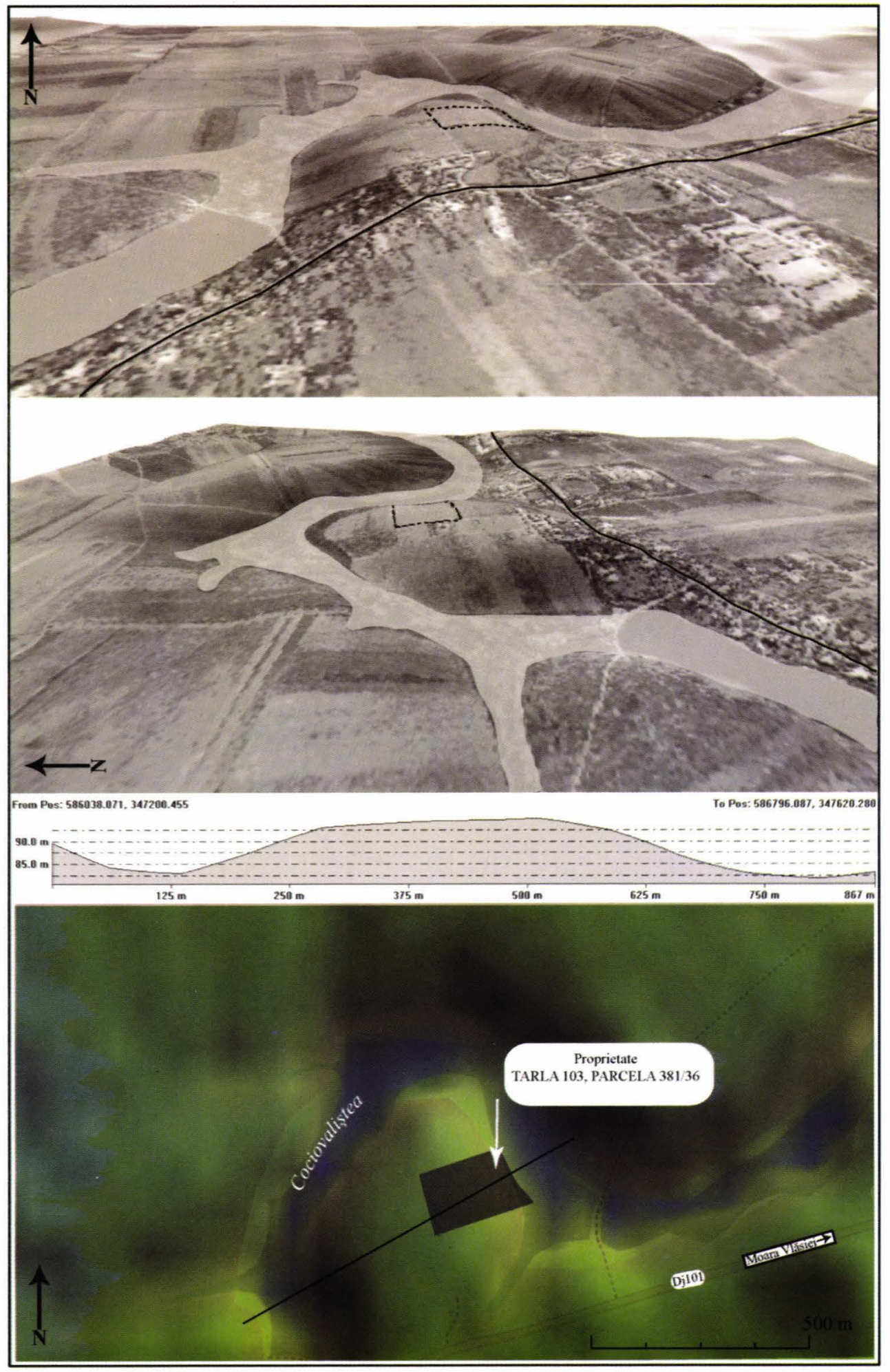

PI. 2 

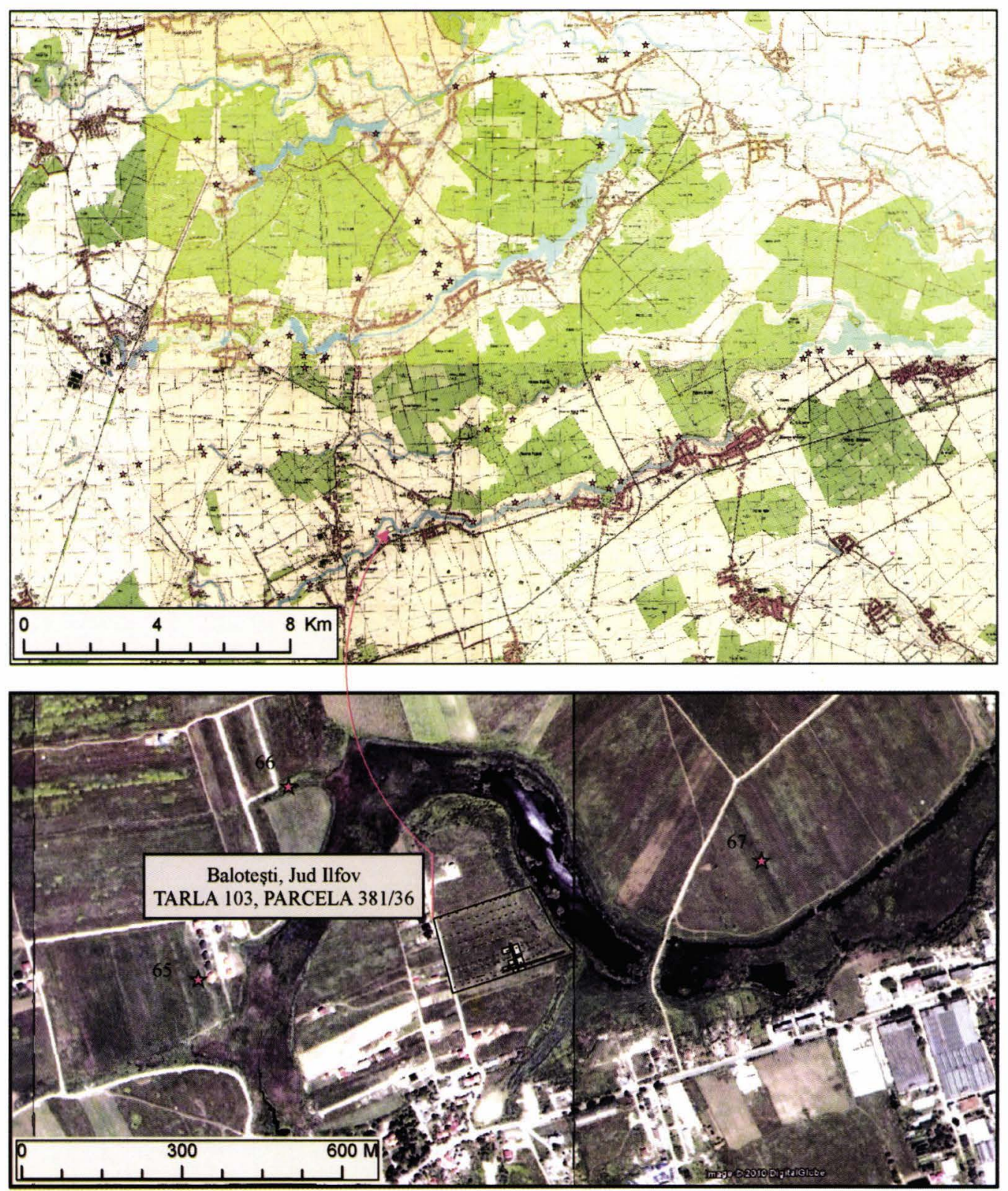

Pl. 3 

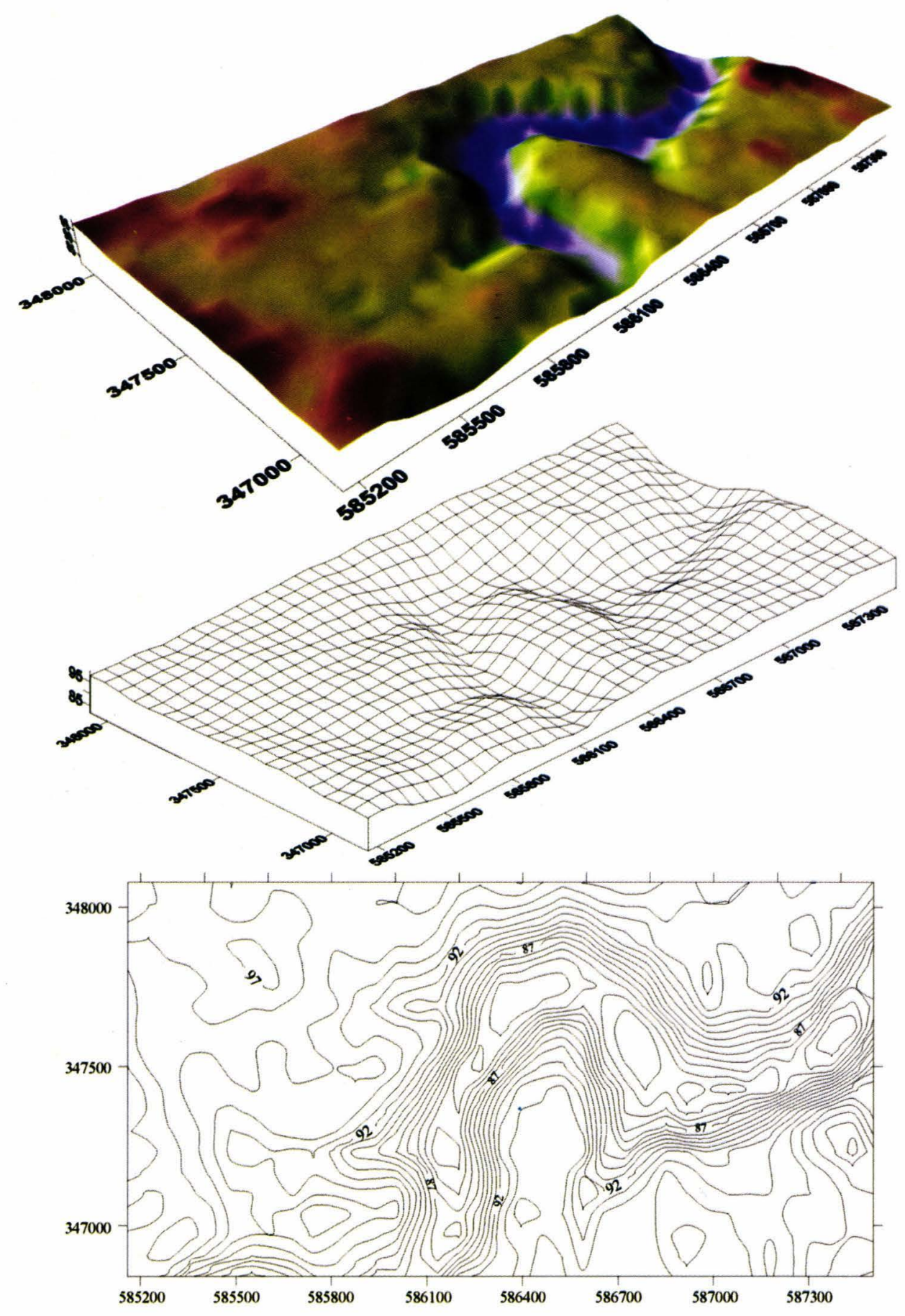

PI. 4 

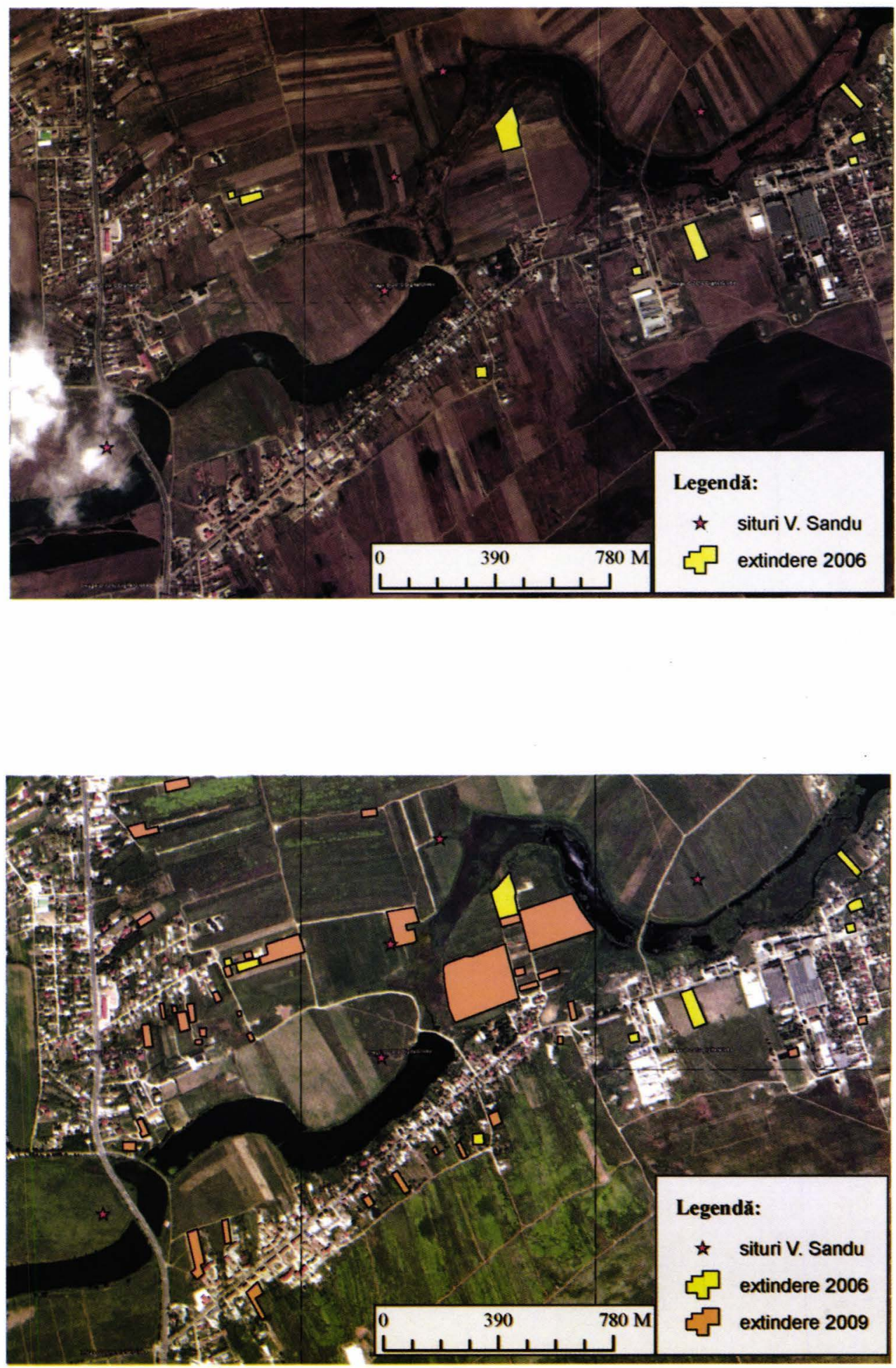

PI. 5 

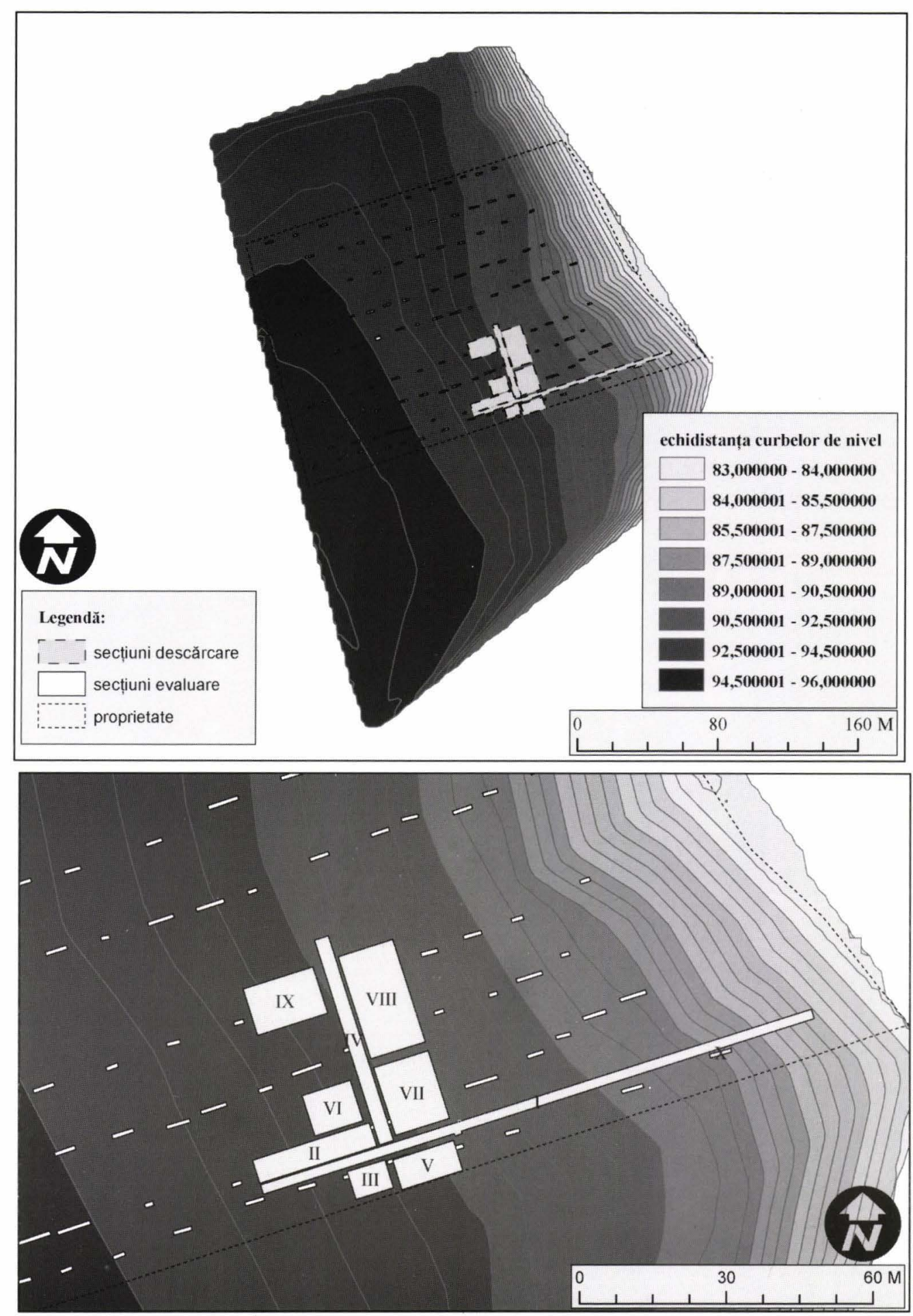

PI. 6 


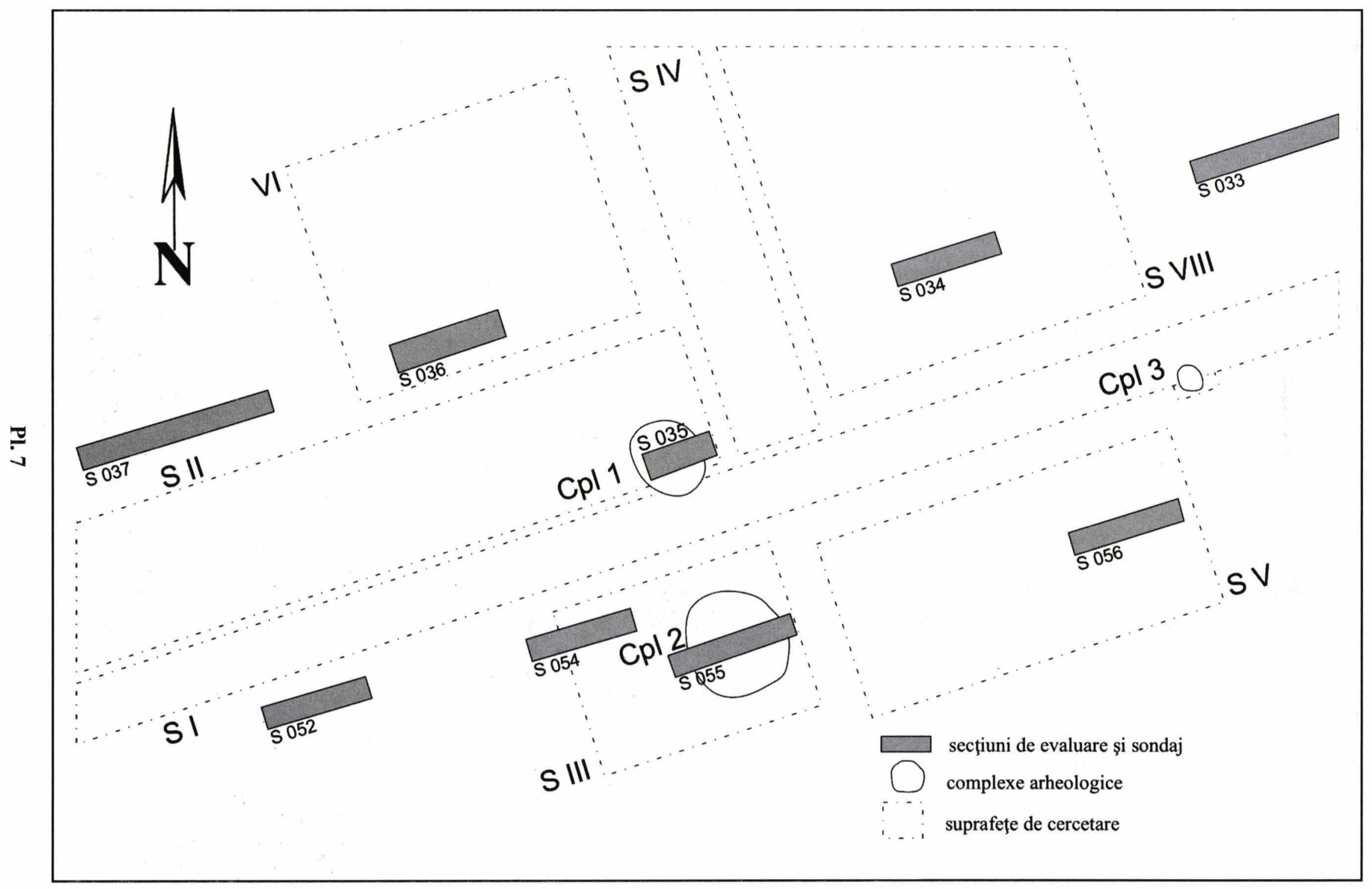




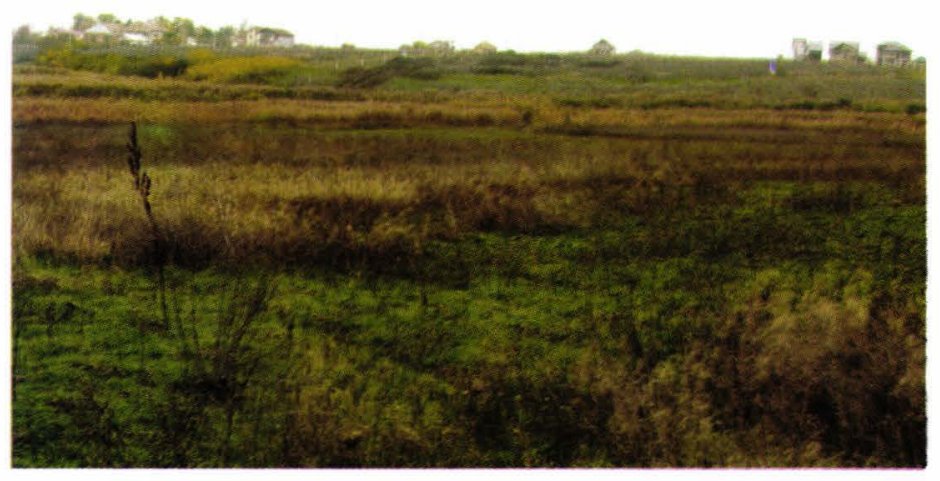

1.
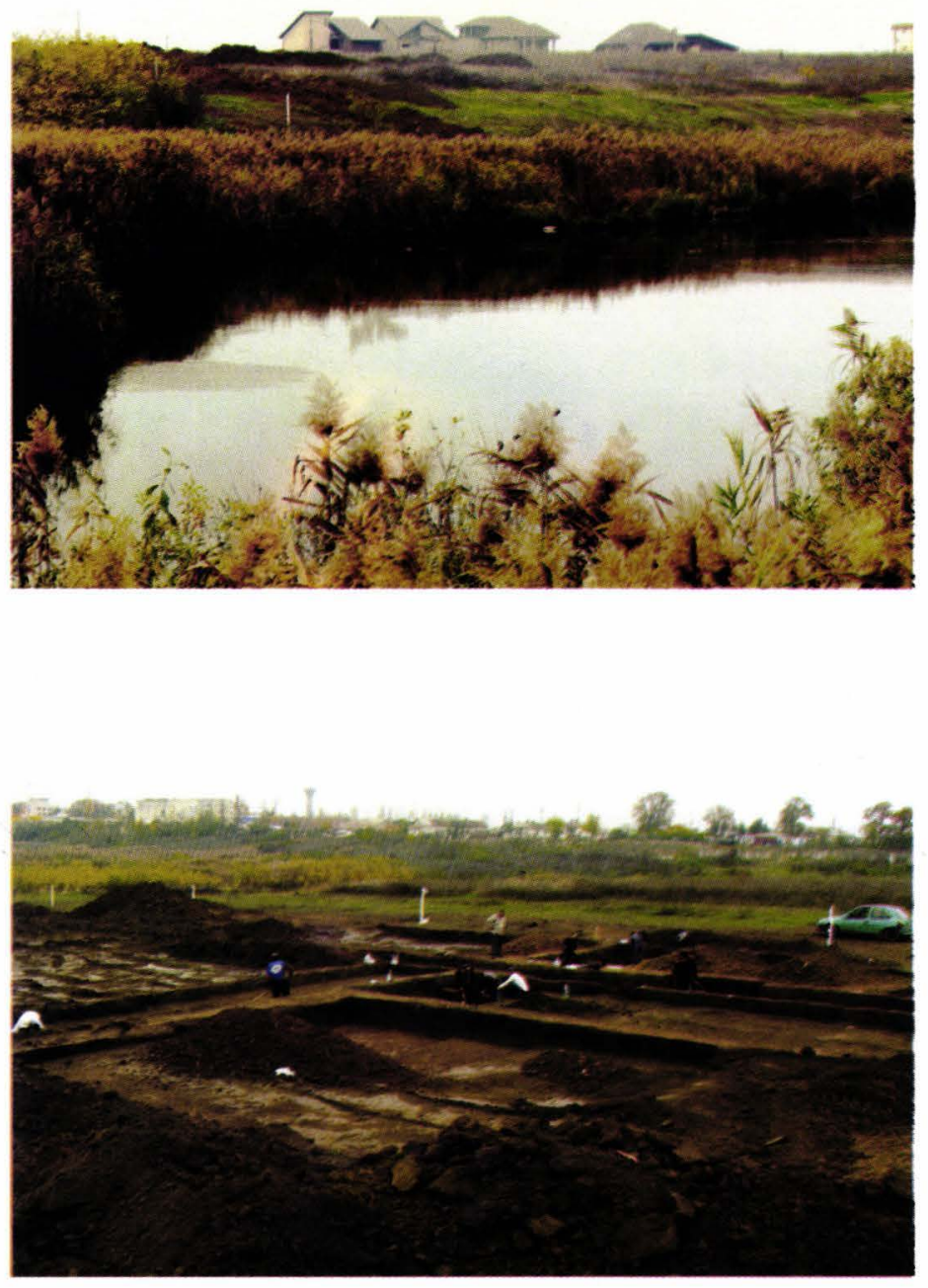

3.

Pl. 8 


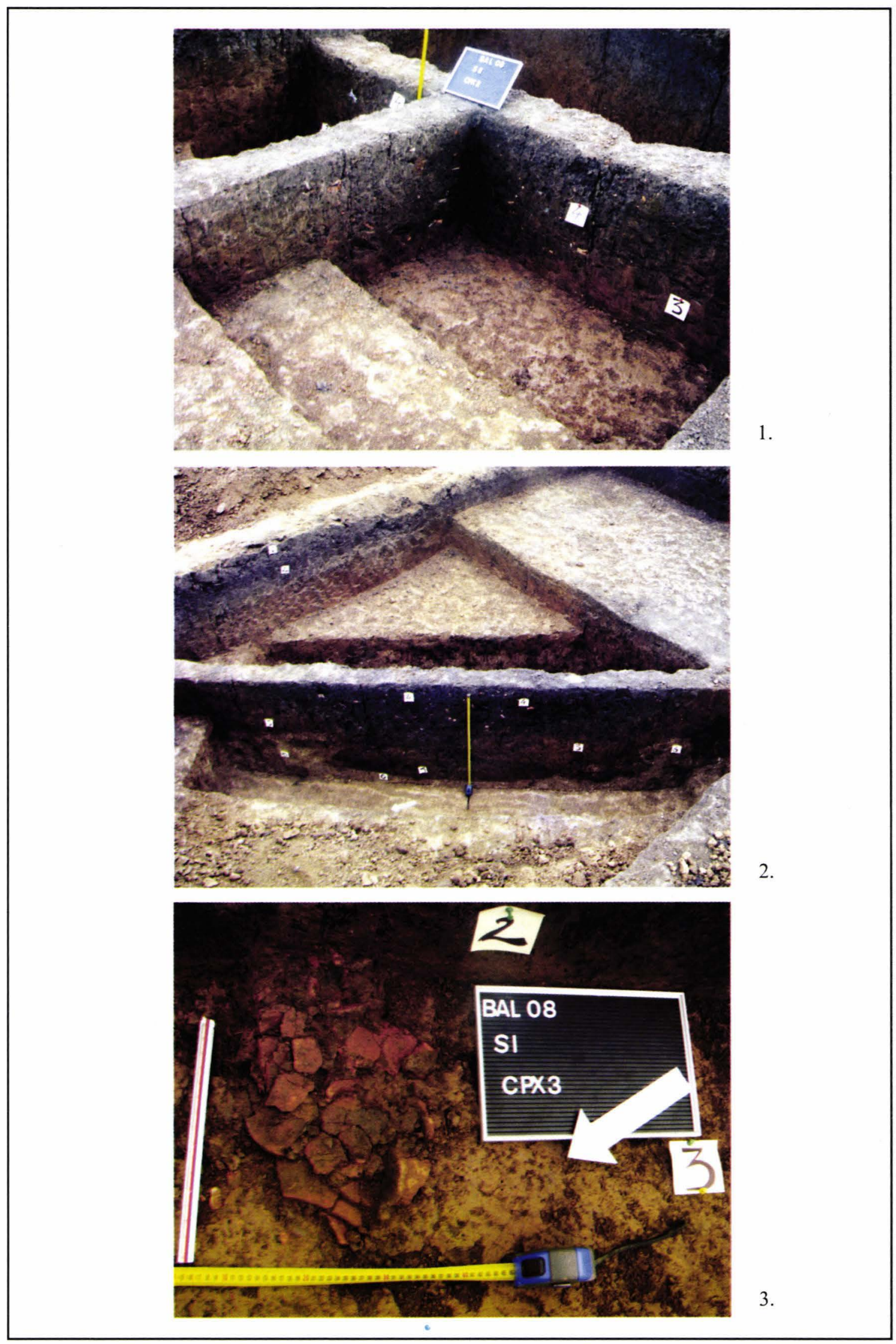

PI. 9 


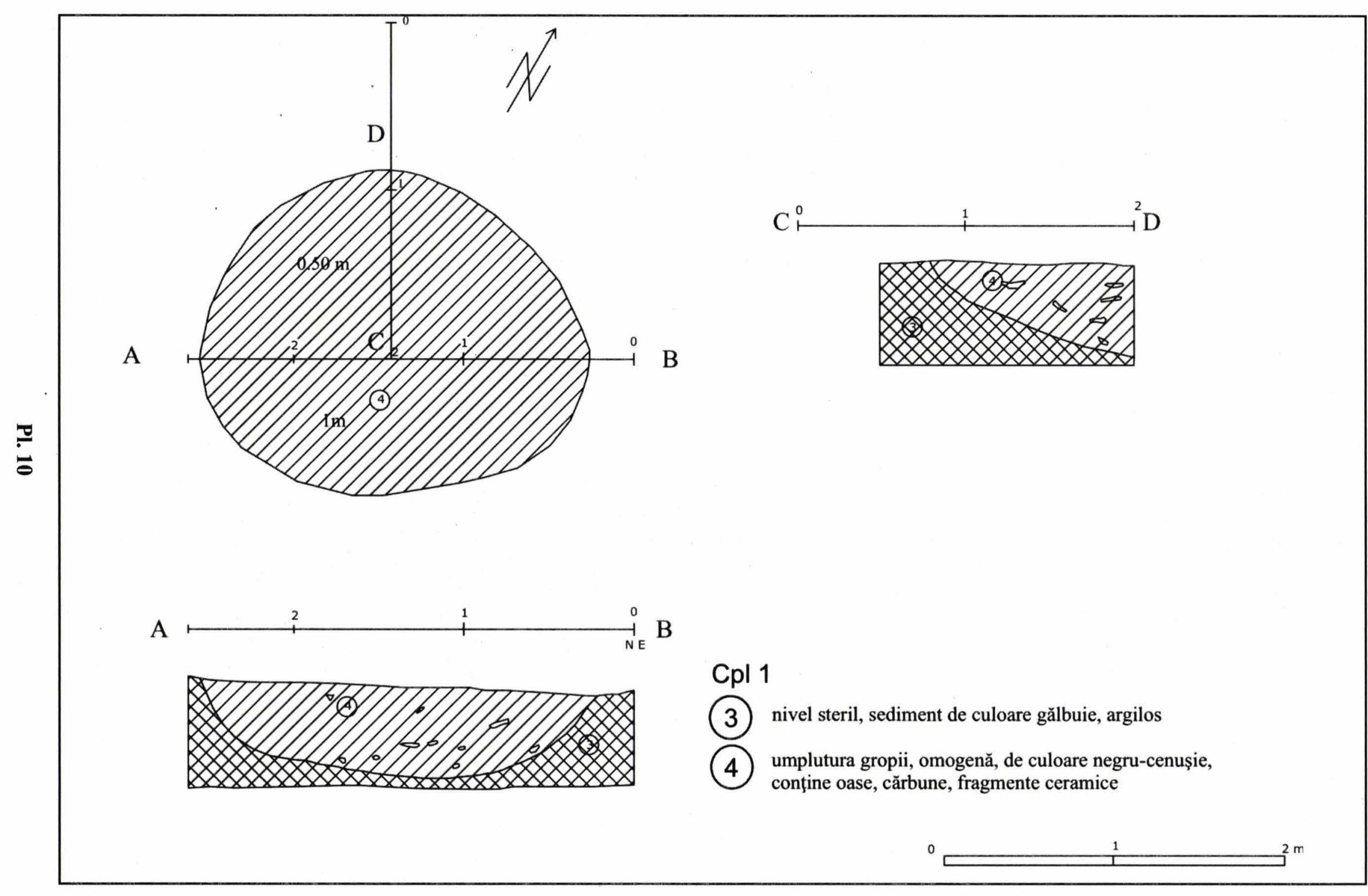




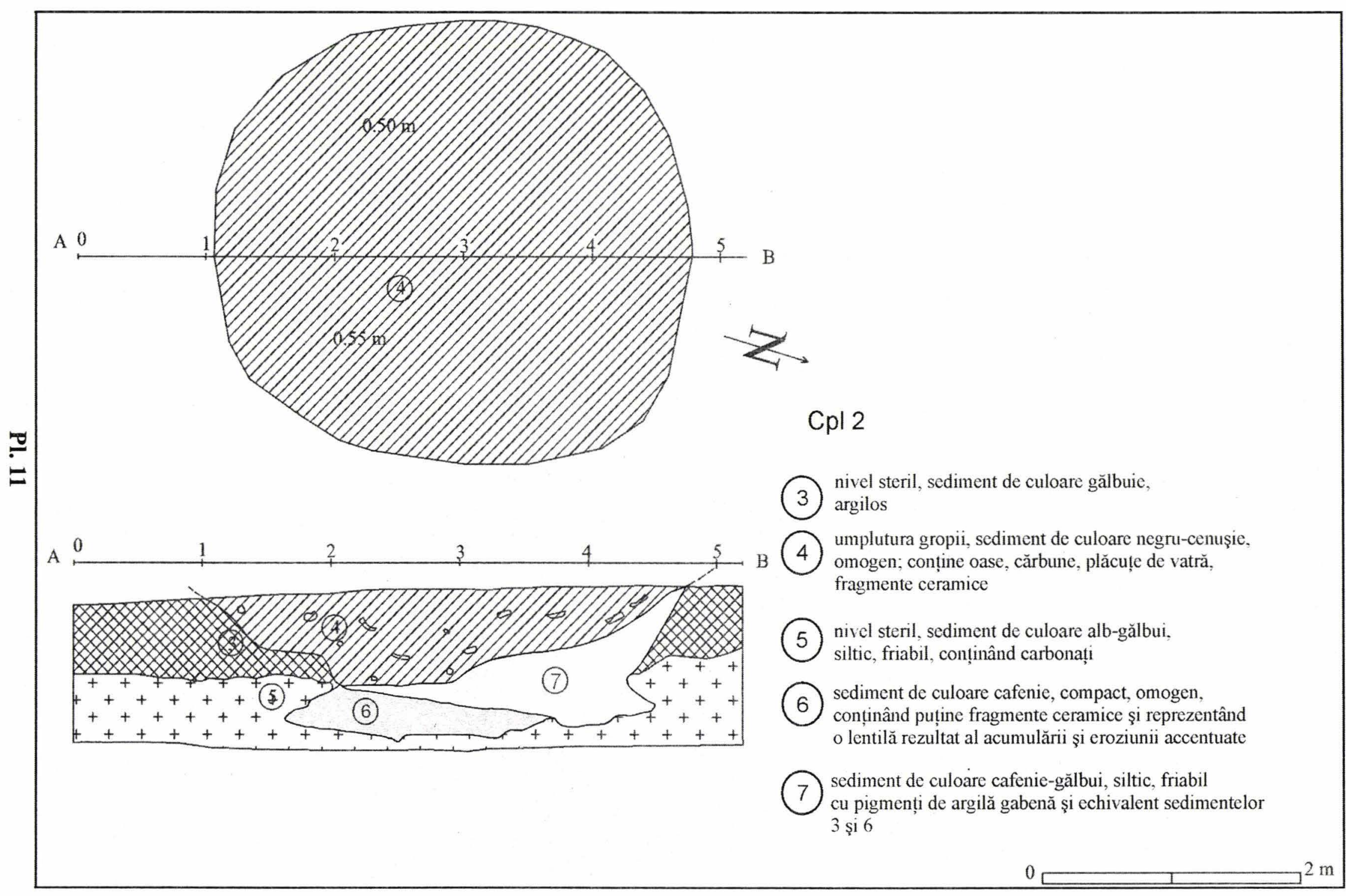




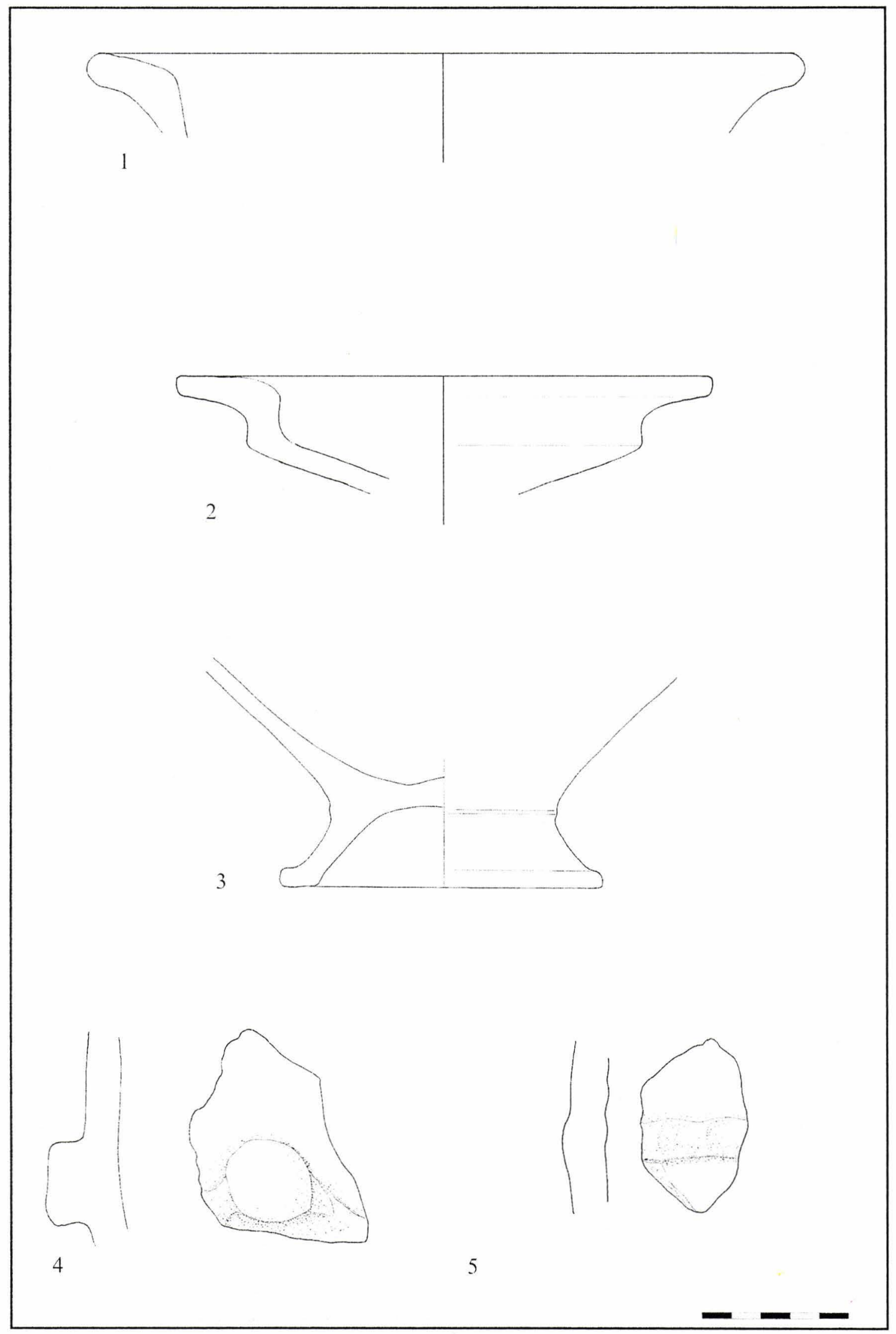

Pl. 12 


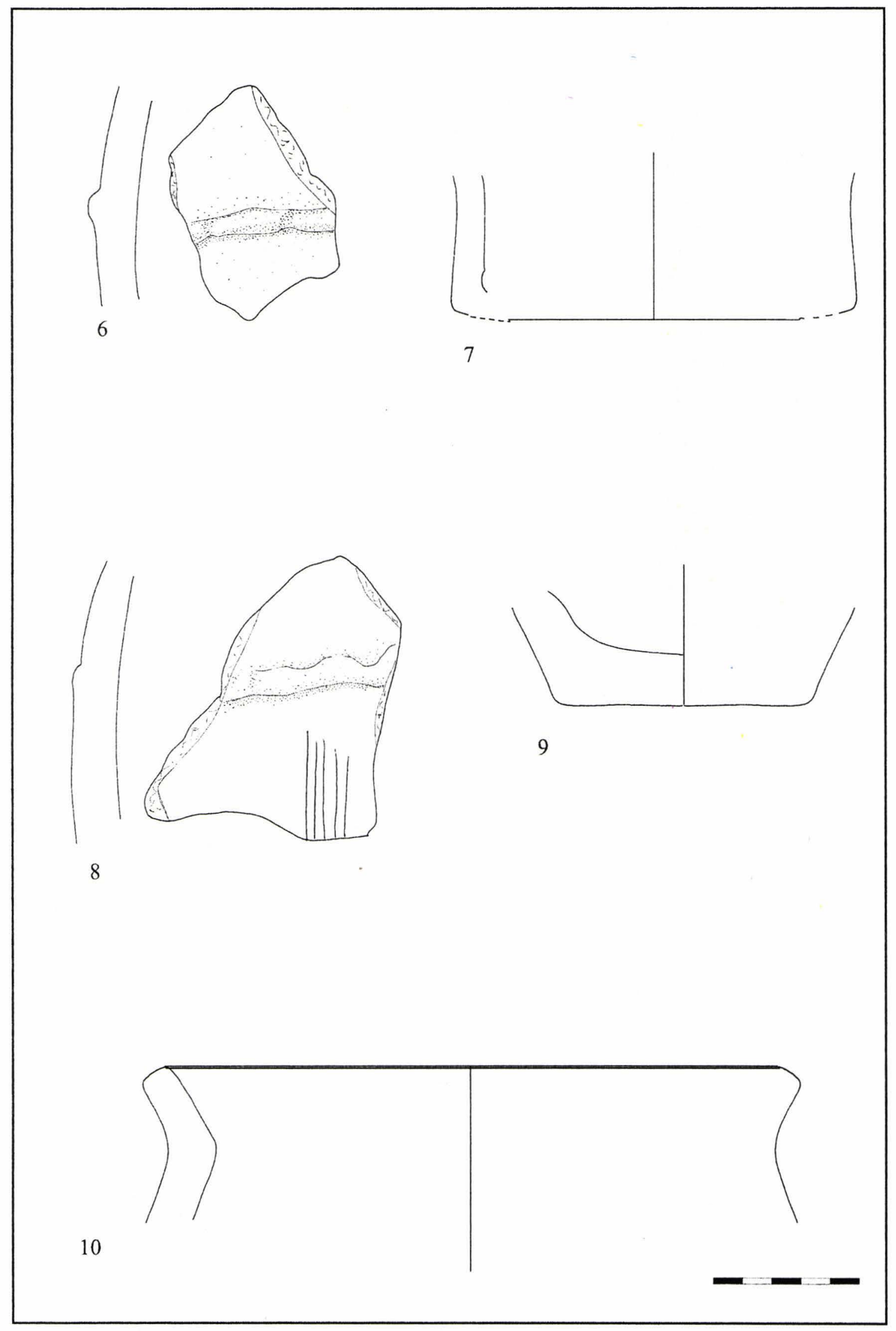

Pl. 13 


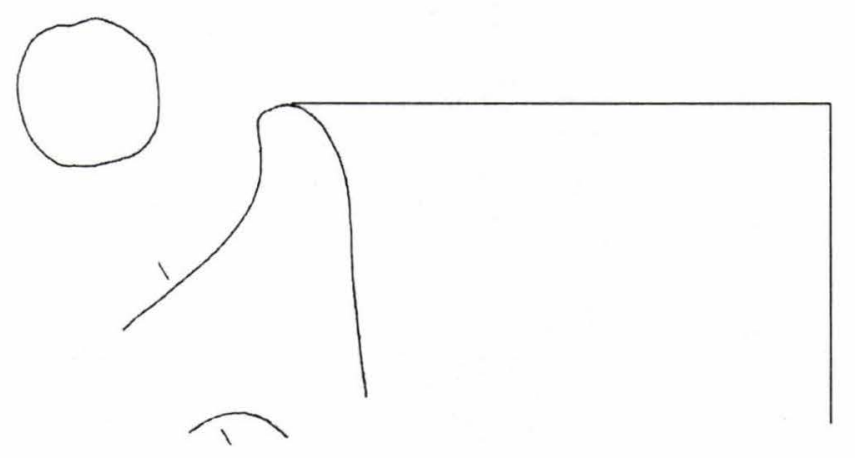

11

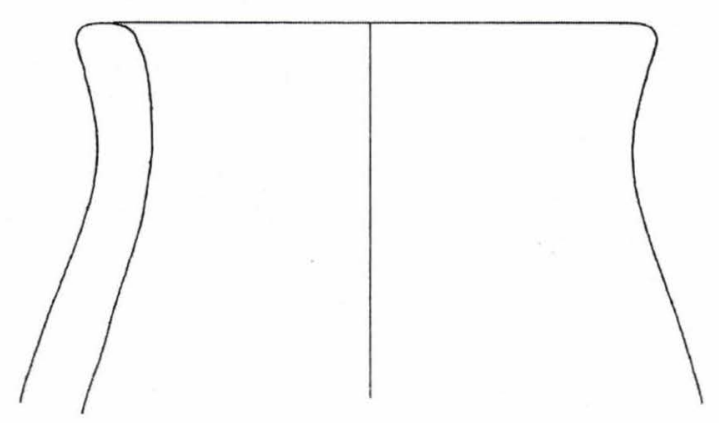

12
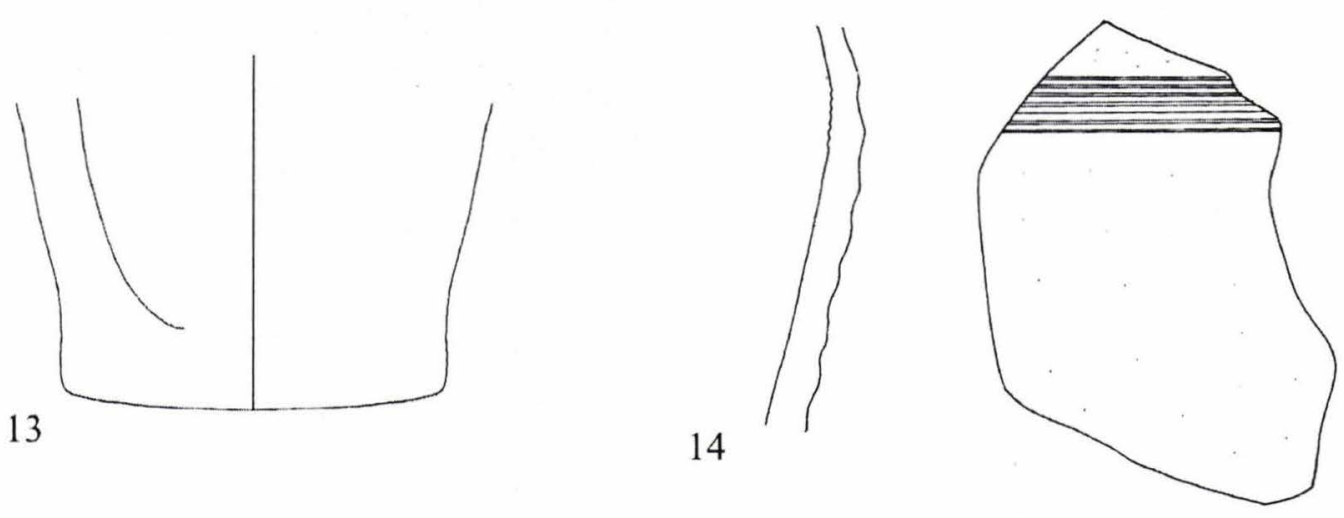

13

14

Pl. 14 


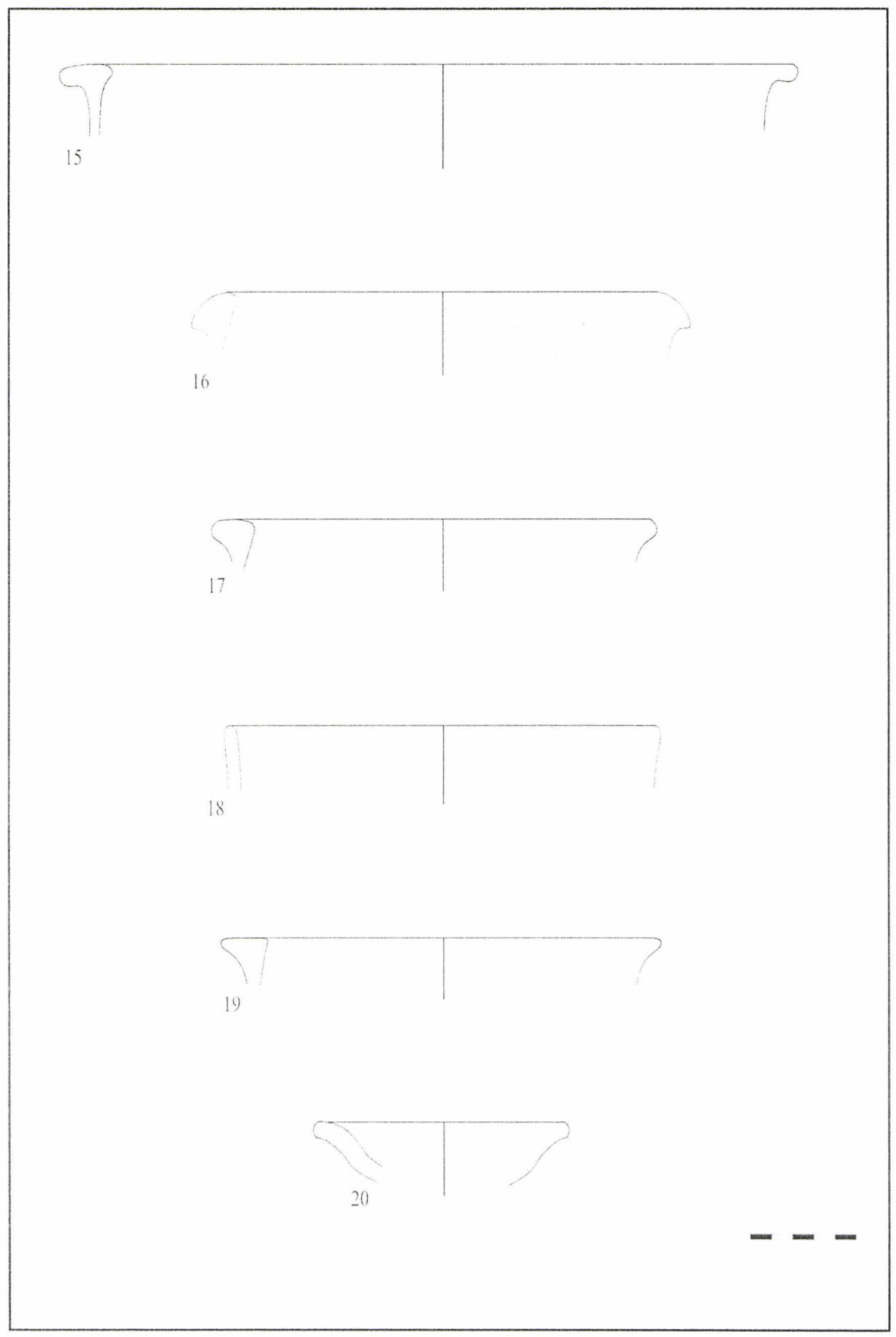

Pl. 15 


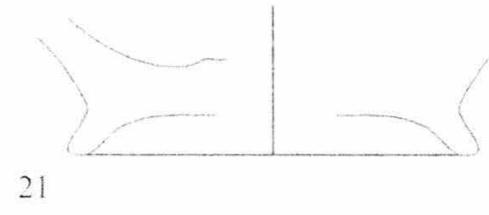

22

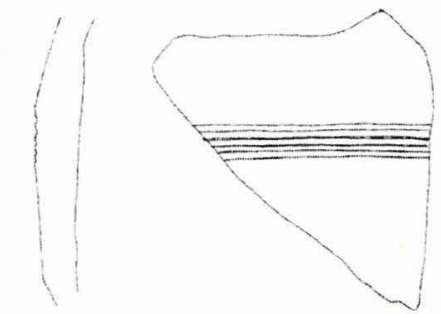

23

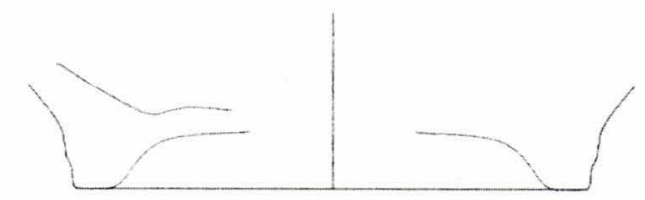

24

Pl. 16 

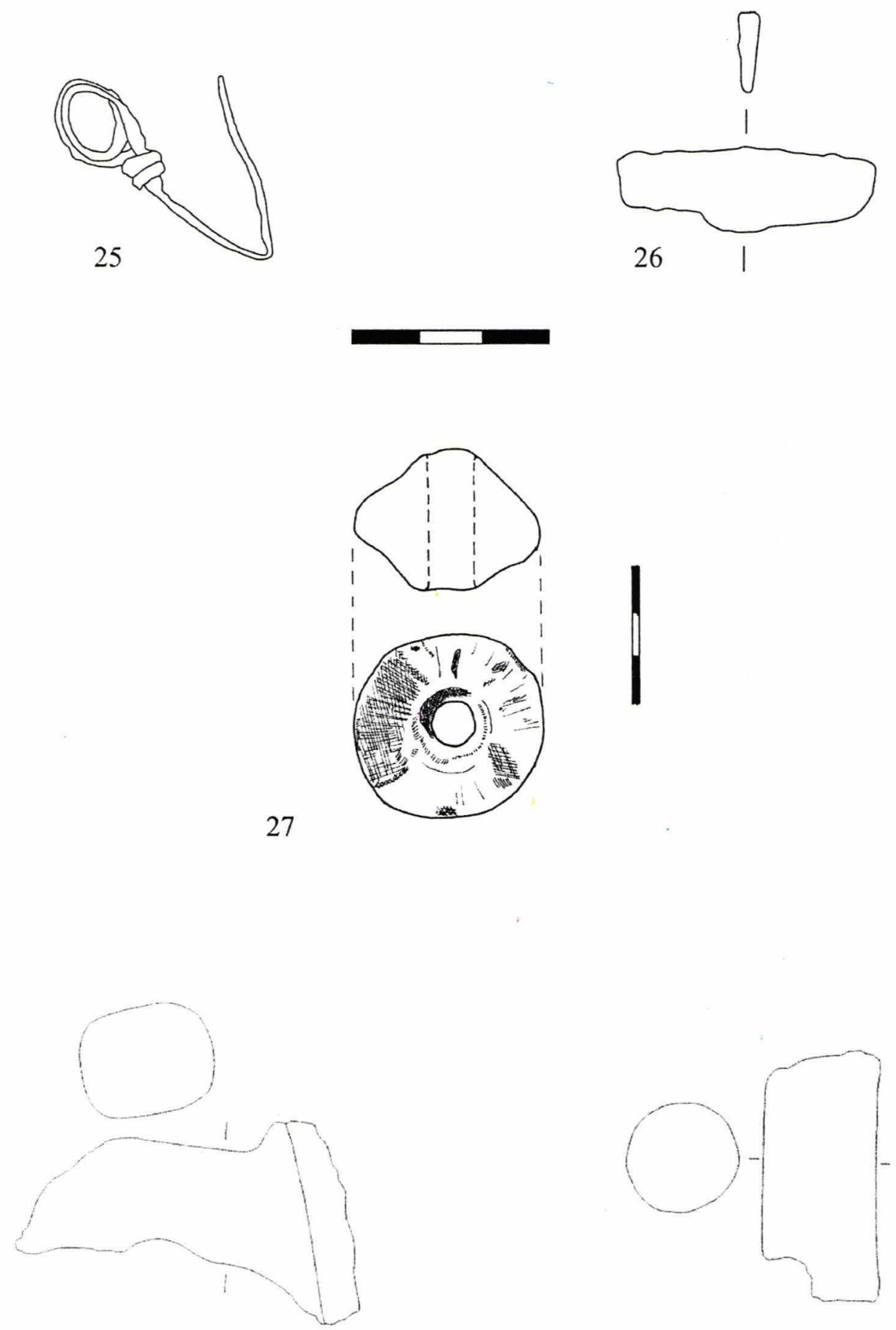

28

PI. 17 


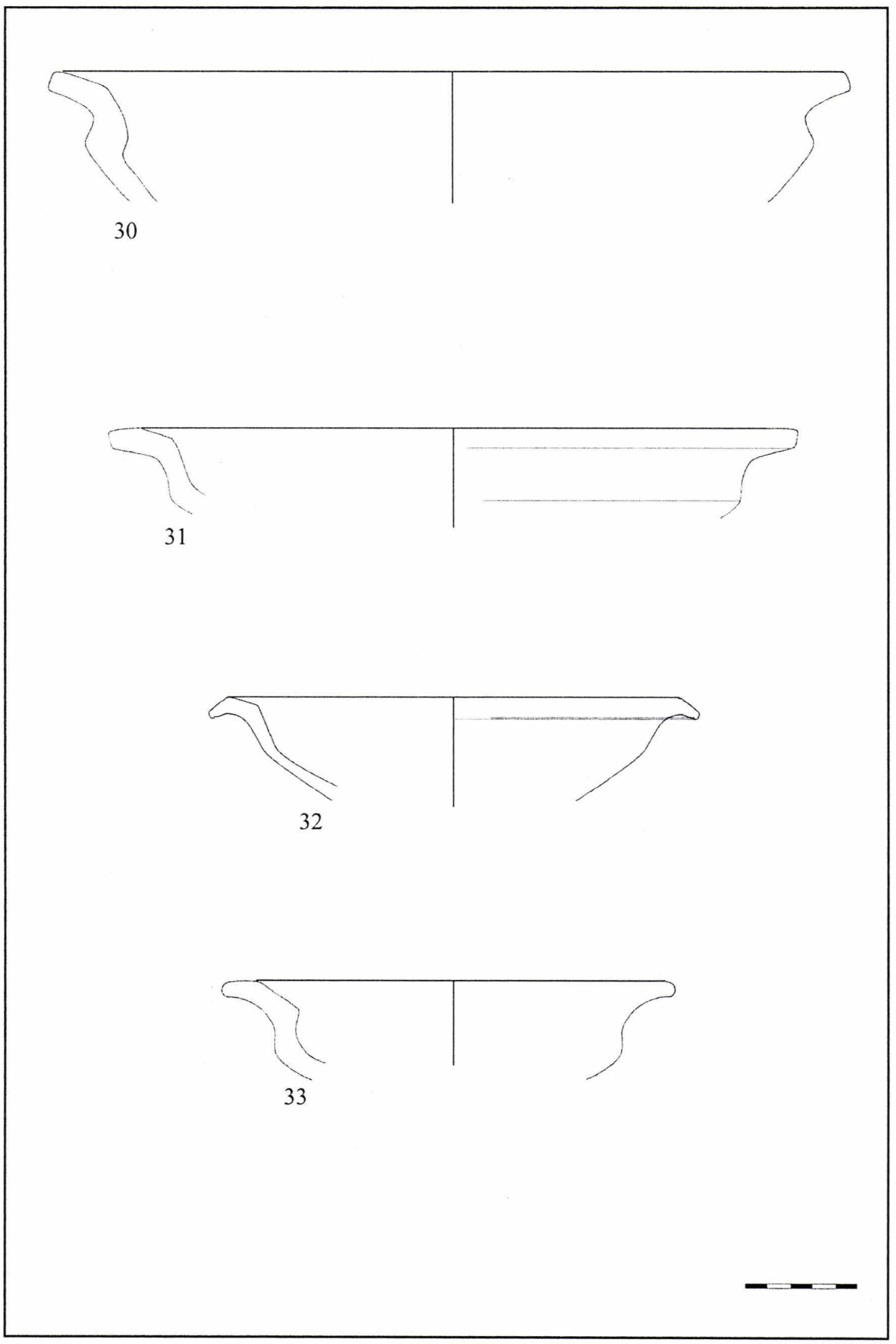

Pl. 18 


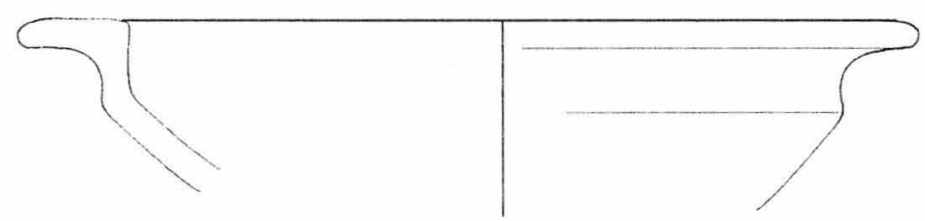

34

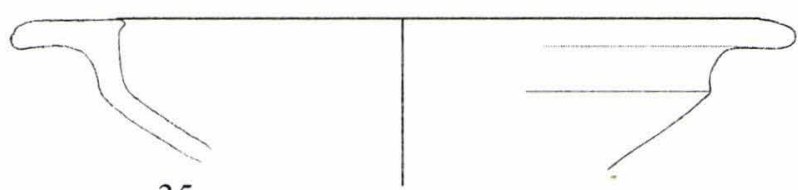

35
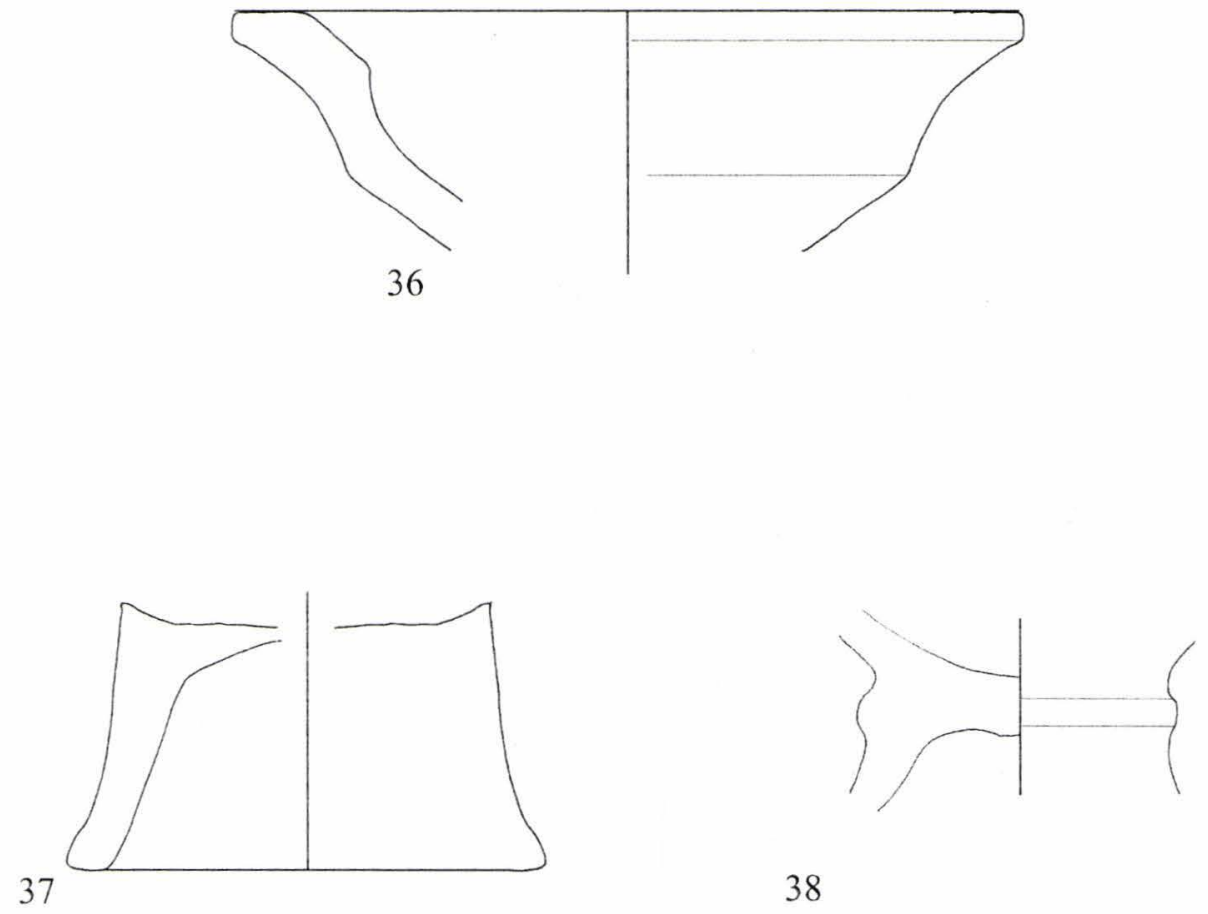

38

PI. 19 


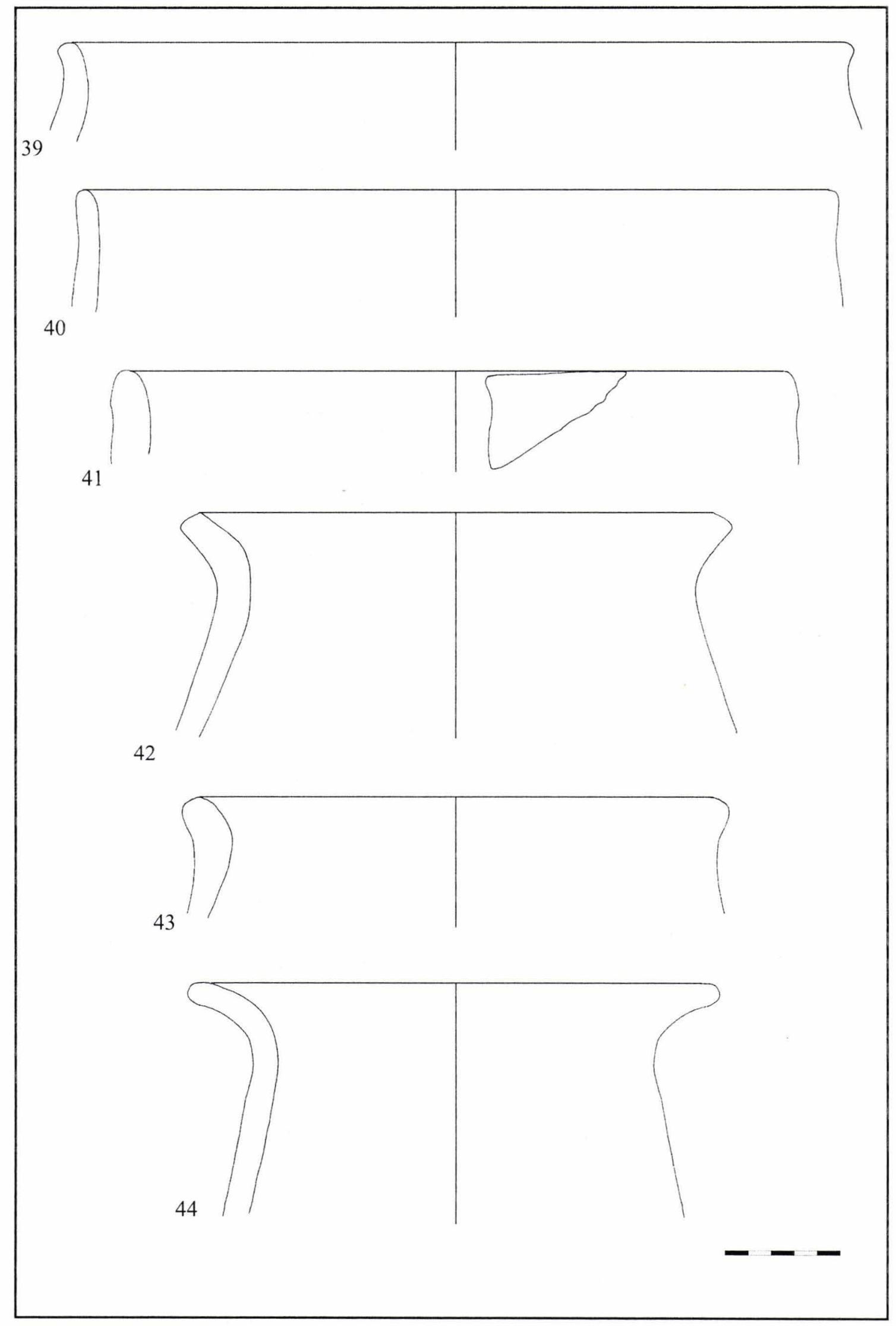

Pl. 20 


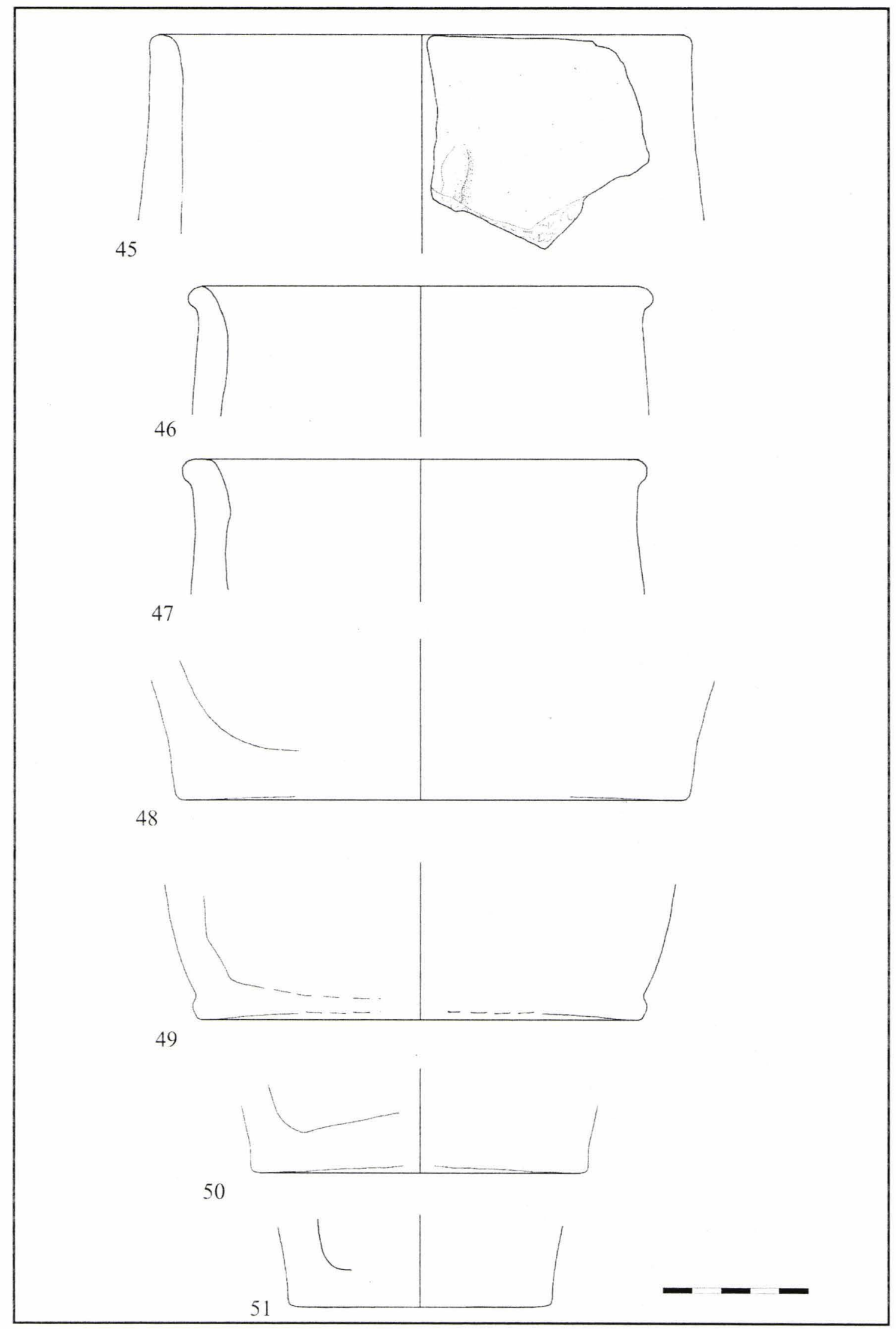

PI. 21 


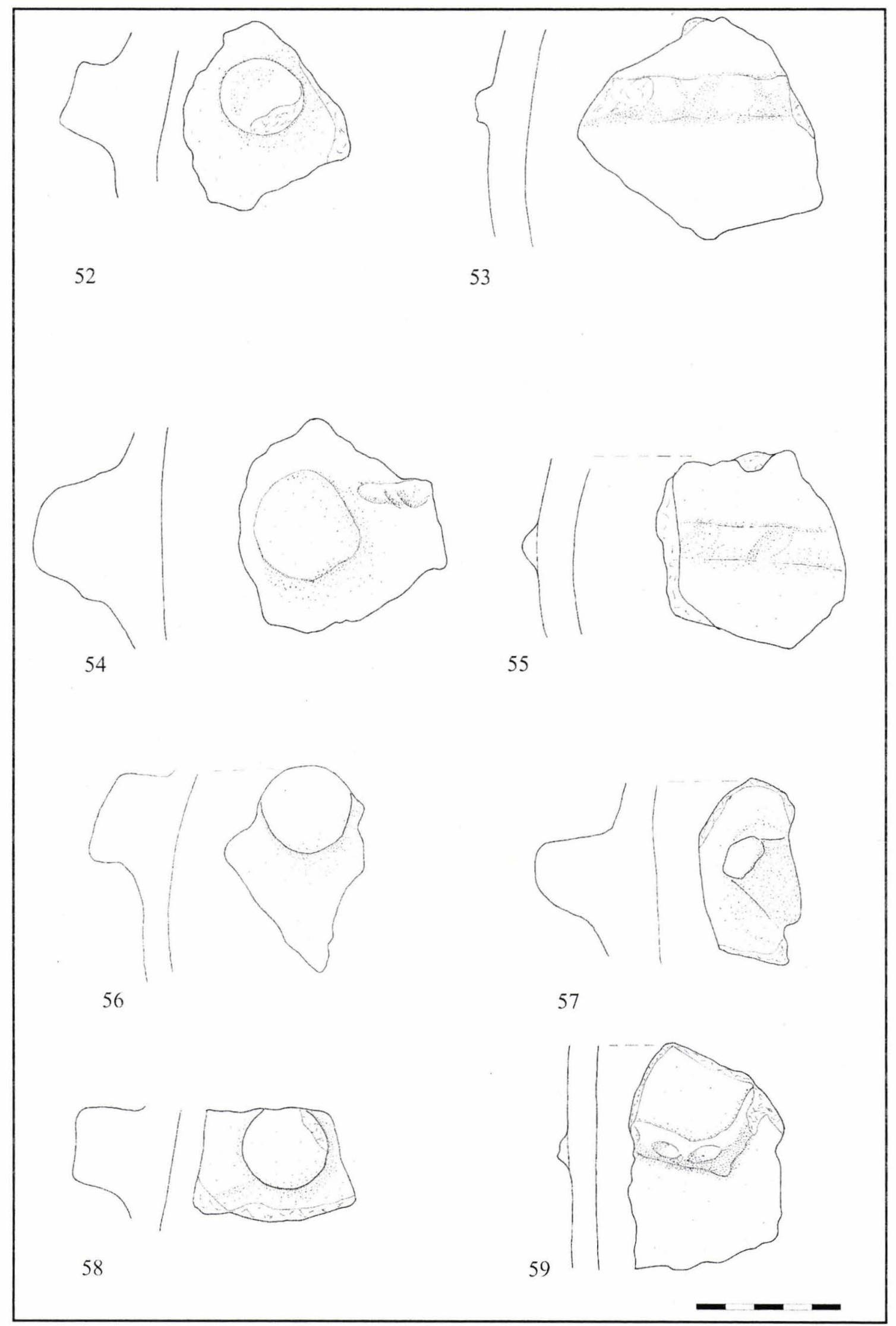

Pl. 22 


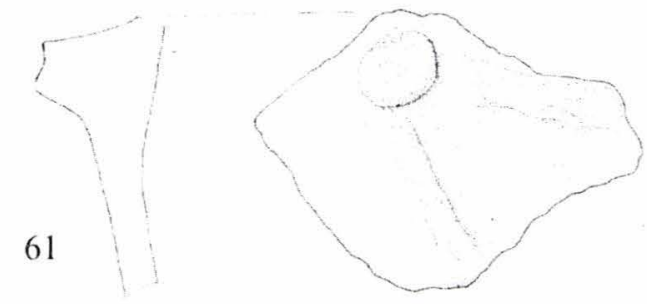

62

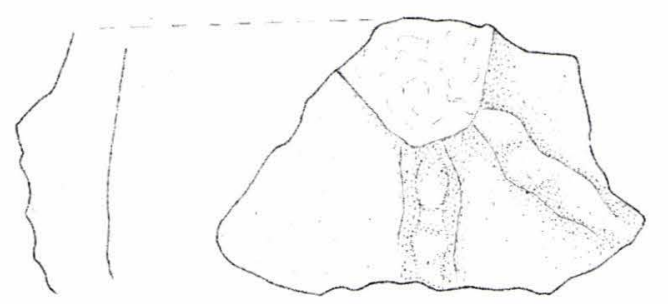

63

64

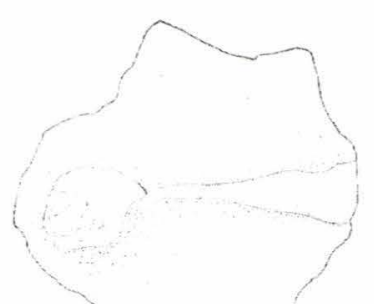

65

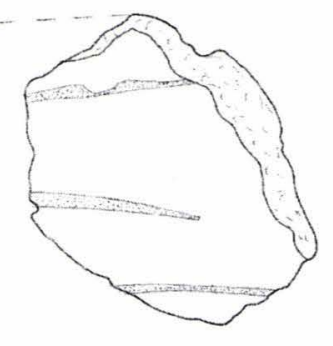

C
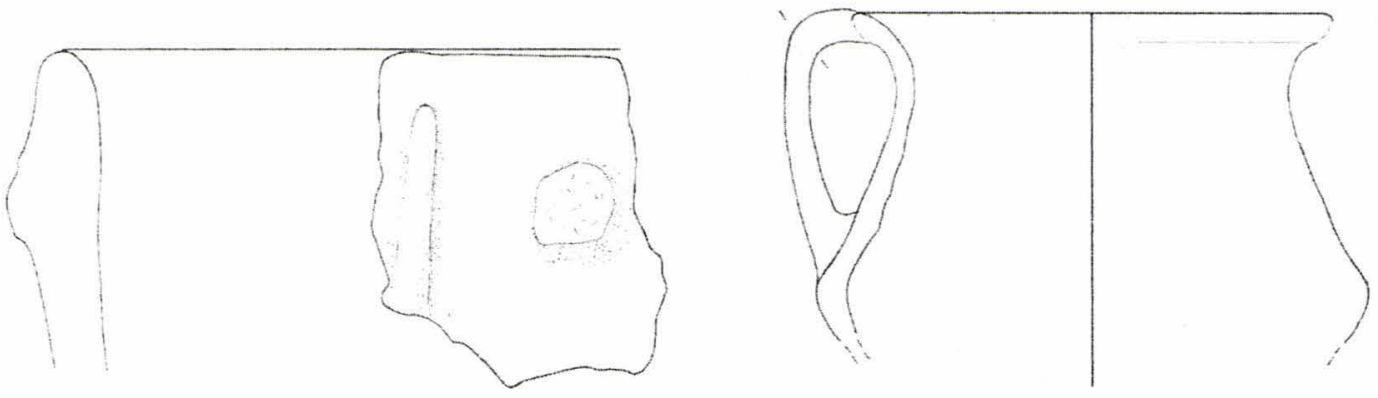

66

67

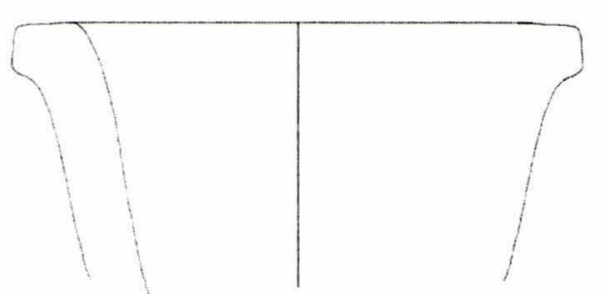

69

68

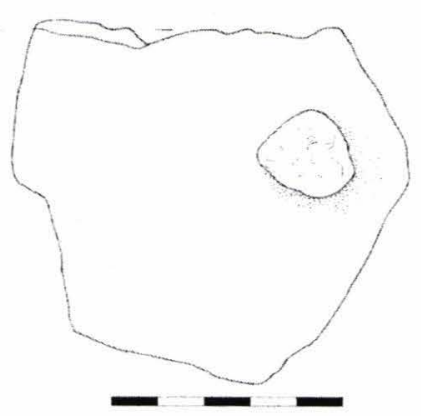

Pl. 23 


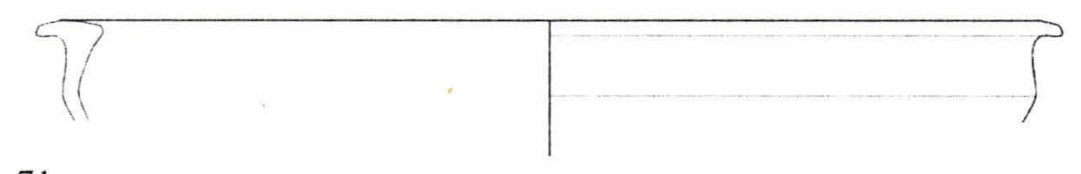

71

72
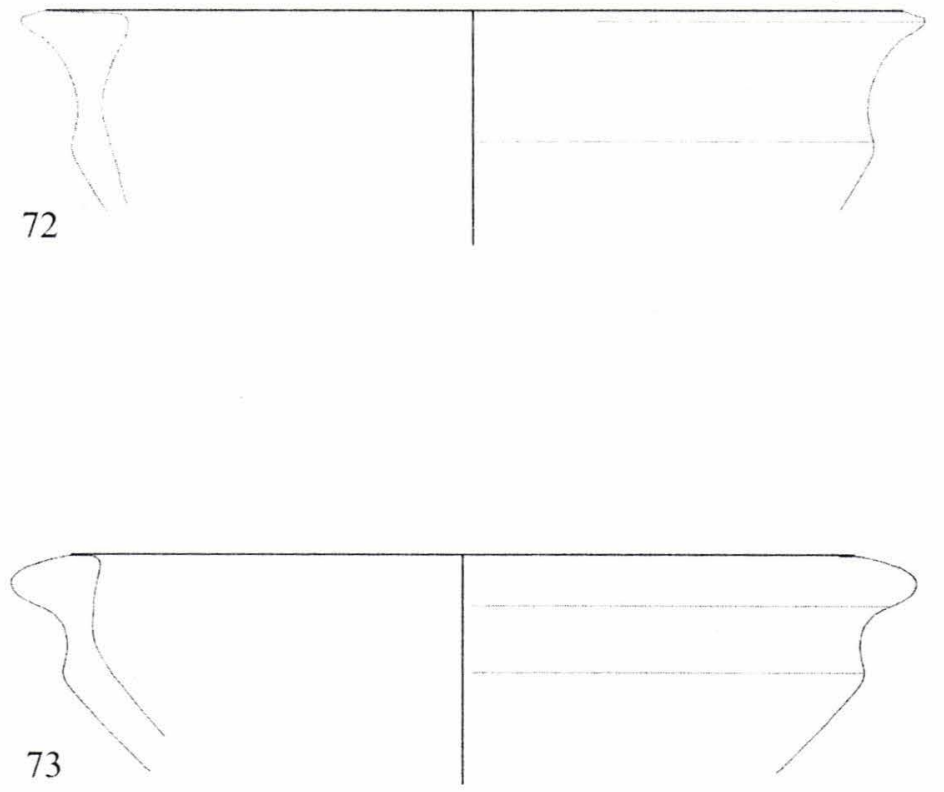

$---$

PI. 24 


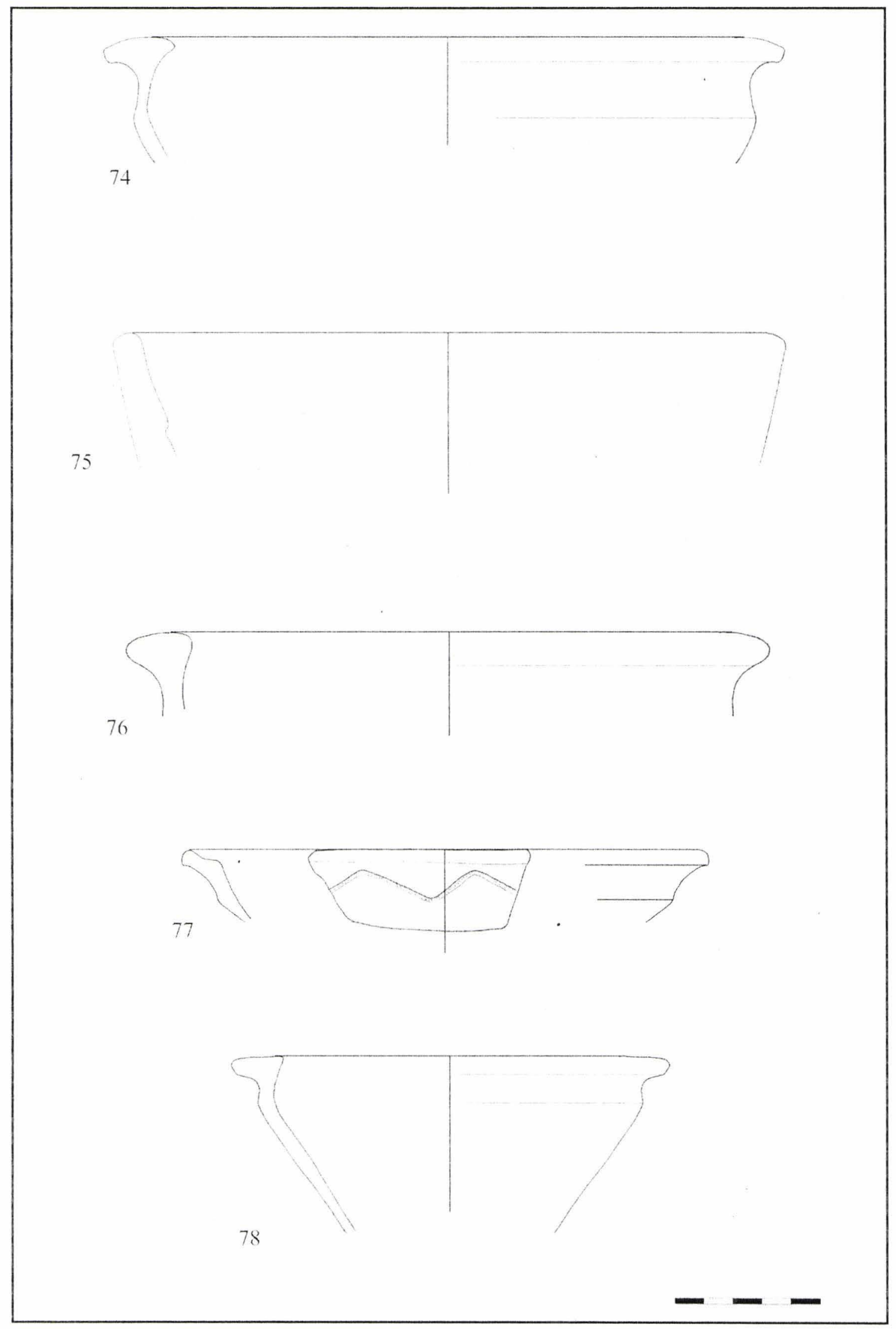

PI. 25 


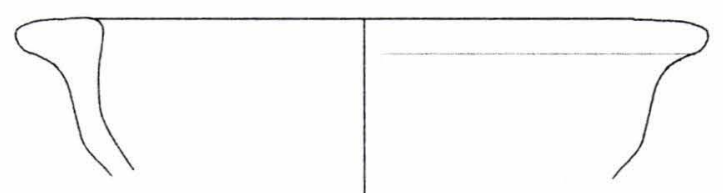

79

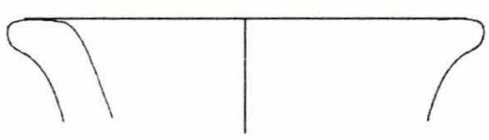

81

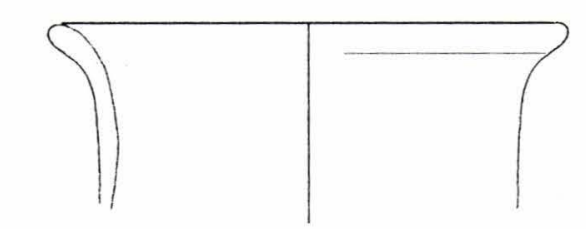

80

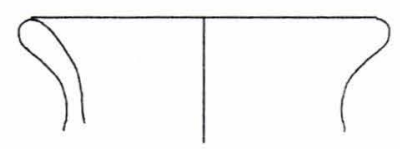

82

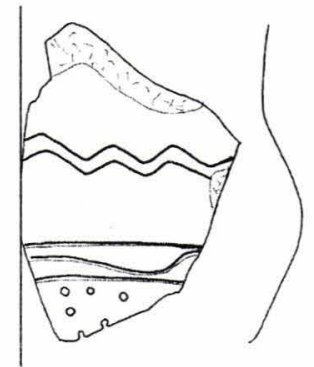

83
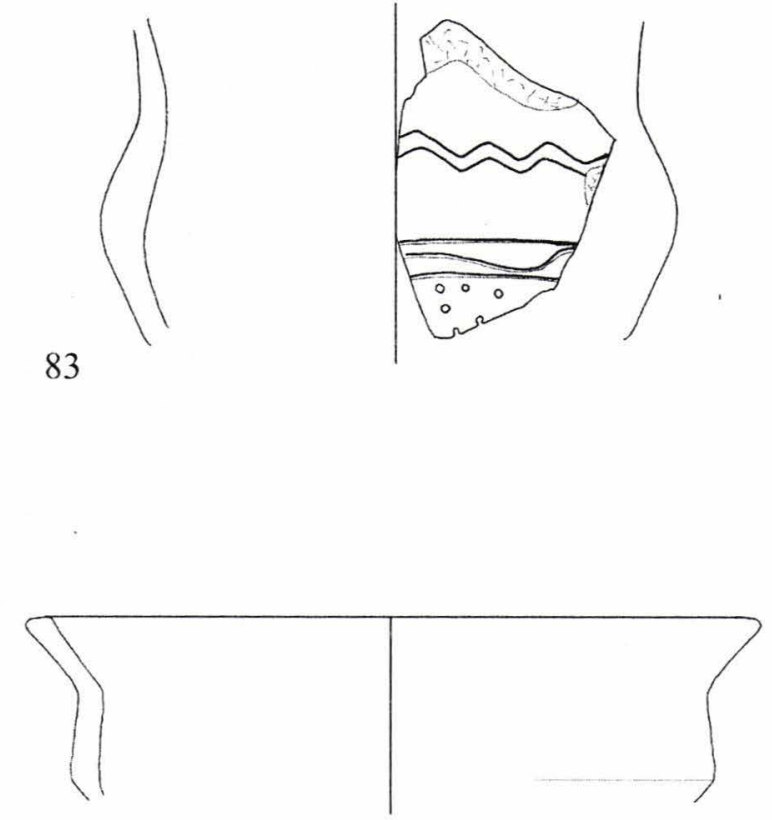

84

Pl. 26 


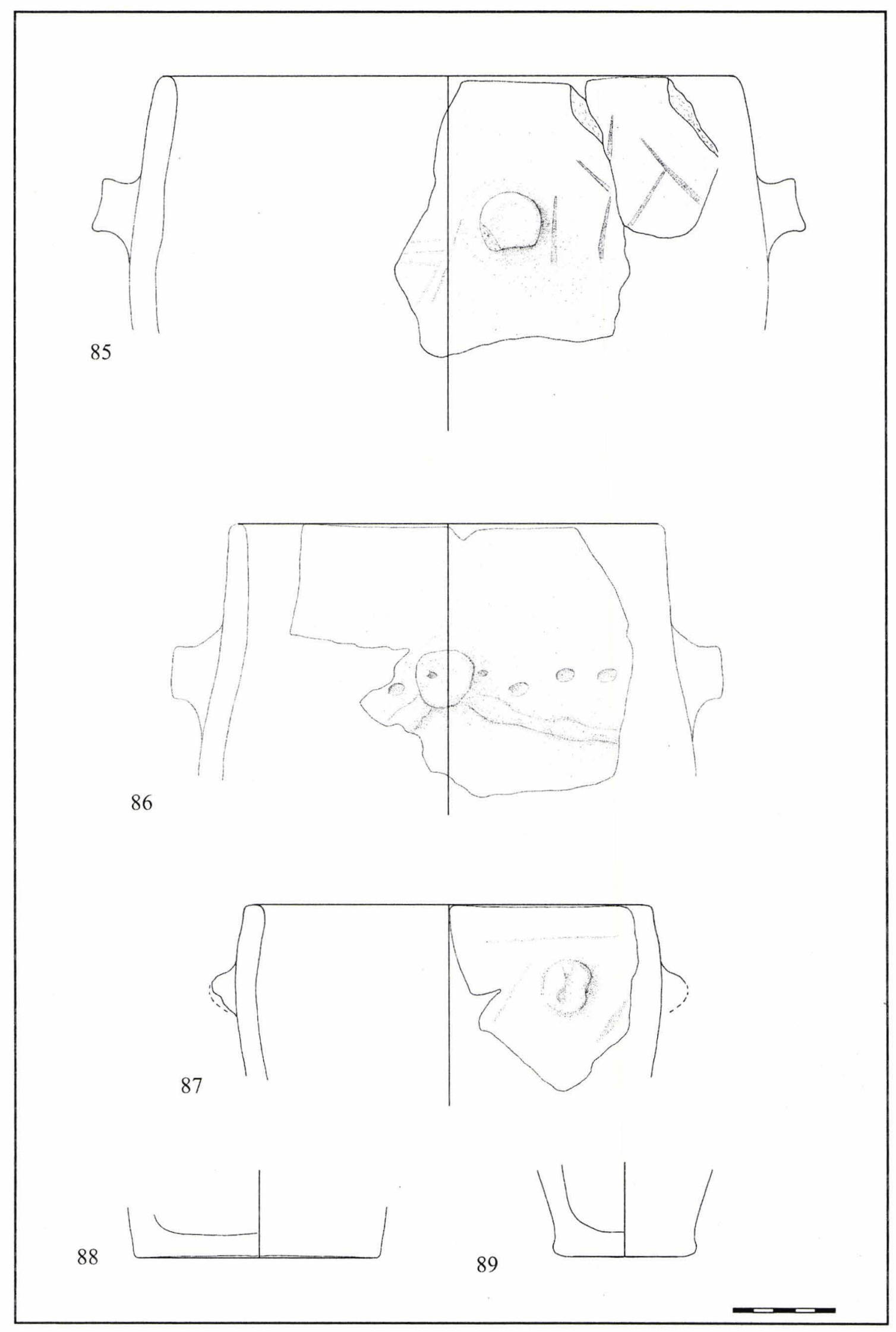

PI. 27 


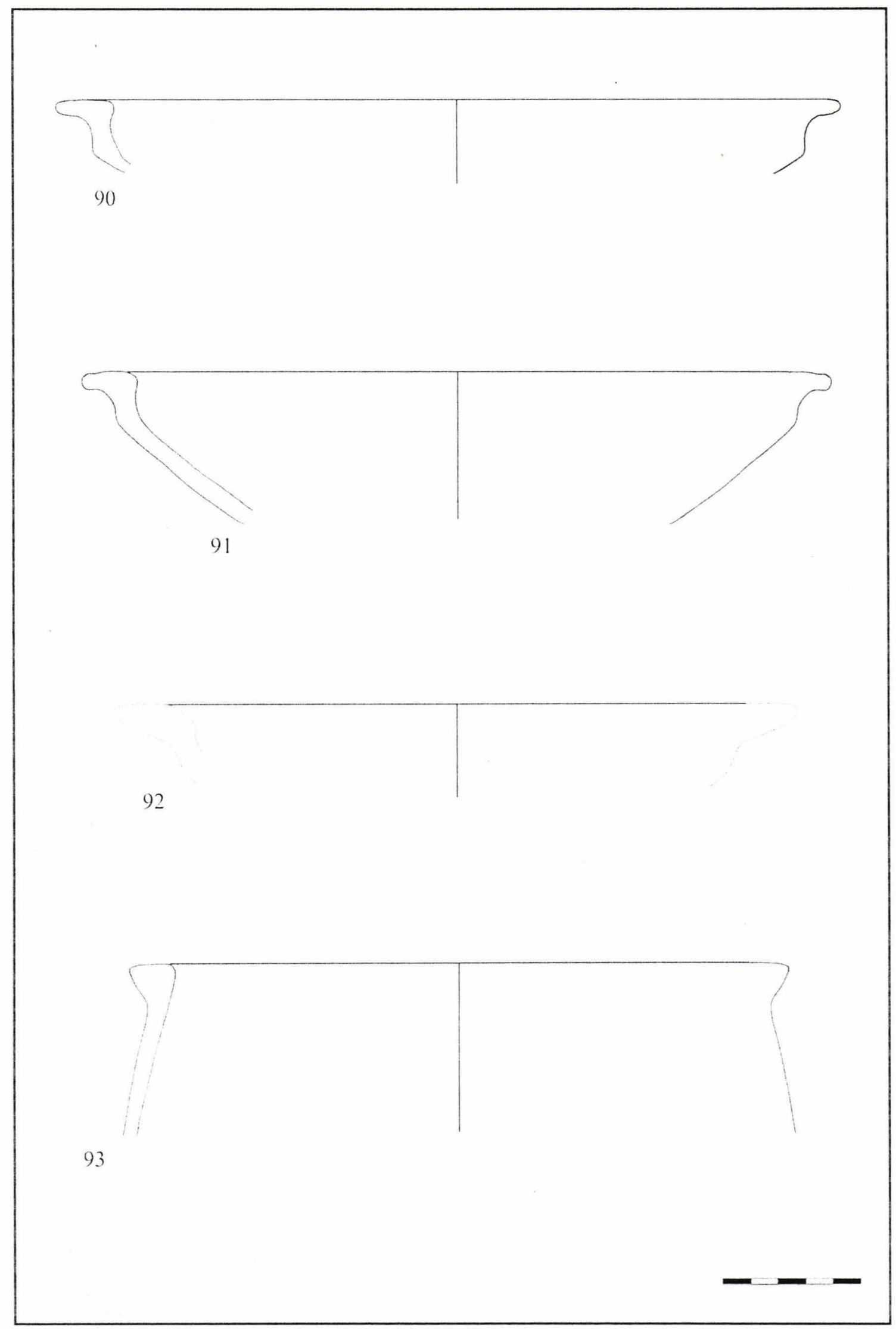

PI. 28 


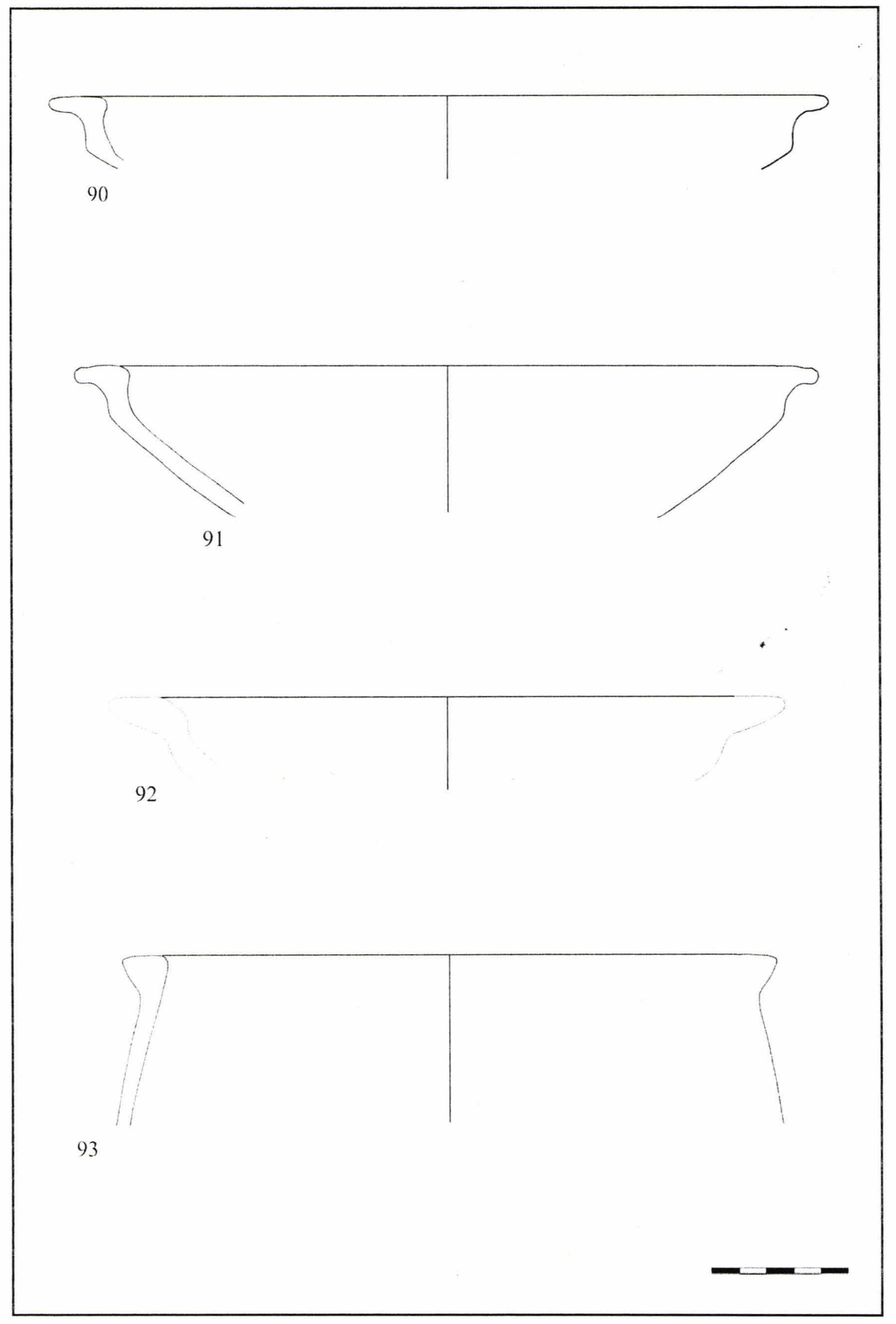

PI. 29 
